\title{
The Letter and the Spirit: A Unified Theory of Originalism
}

Randy E. Barnett

Georgetown University Law Center, rb325@law.georgetown.edu

Evan Bernick

Georgetown University Law Center, eb860@law.georgetown.edu

This paper can be downloaded free of charge from:

https://scholarship.law.georgetown.edu/facpub/2000

https://ssrn.com/abstract=3049056

107 Geo. L.J. 1

This open-access article is brought to you by the Georgetown Law Library. Posted with permission of the author. Follow this and additional works at: https://scholarship.law.georgetown.edu/facpub

Part of the Constitutional Law Commons 


\title{
ARTICLES
}

\section{The Letter and the Spirit: A Unified Theory of Originalism}

\author{
RANDY E. BARnETT* \& EvAN D. BERNICK**
}

The concept of constitutional construction is of central importance to originalist theory but is both underdeveloped and controversial among originalists. Some object that its apparent open-endedness undermines the constraining virtues of originalism and exposes citizens to arbitrary judicial power. In this Article, we respond to this challenge by presenting an originalist theory of constitutional construction that can guide and constrain judicial activity within the "construction zone." When combined with an originalist theory of constitutional interpretation, our approach yields a unified theory of originalism.

Our theory of constitutional construction draws upon a familiar common-law concept long used in contract and fiduciary law to handle the problem of opportunistic abuse of discretion: the duty of good faith. We contend that judges who take an oath to "support this Constitution" enter into a fiduciary relationship with private citizens-a relationship characterized by discretionary powers in the hands of judges and a corresponding vulnerability in the citizenry. As fiduciaries, judges are morally and legally bound to follow the instructions given to them in "this Constitution" in good faith. This means that judges engaging in constitutional construction (or "implementation") must seek to give legal effect to both the Constitution's "letter" (its original public meaning) and its "spirit" (the original function or purpose of the particular clauses and general structure of the text).

Therefore, when interpretation of original meaning is not sufficient to resolve a controversy, judges have a duty to employ good-faith construction. Good-faith construction consists of (a) accurately identifying

\footnotetext{
* Carmack Waterhouse Professor of Legal Theory, Georgetown University Law Center; Director, Georgetown Center for the Constitution. (C) 2018, Randy E. Barnett \& Evan D. Bernick. We thank the participants in Seventh Annual Hugh \& Hazel Darling Foundation Originalism Works-in-Progress Conference, held at the University of San Diego School of Law in February of 2016-and especially John McGinnis, our designated commentator-for constructive criticisms of an earlier paper. The analysis presented in that paper-and even its basic thesis - has been so substantially revised that this is, for most intents and purposes, a different paper. We are also very grateful to Joel Alicea and Larry Solum for detailed feedback on the previous version as well as our subsequent revisions, as well as to Mike Ramsey, Sai Prakash, and Eric Claeys for their helpful suggestions. We also benefited from the feedback we received at the Public Law Colloquium at Northwestern Law School, and at faculty workshops at Antonin Scalia and Georgetown law schools. Permission to distribute for educational purposes is hereby granted.

** Visiting Lecturer, Georgetown University Law Center; Fellow, Georgetown Center for the Constitution.
} 
the spirit—or "original function" -of the relevant constitutional provision at the time it was enacted and (b) devising implementing rules that are calculated to give effect to both the letter and the spirit of the text in the case at hand and in future cases. Conversely, bad-faith construction consists in opportunistically using the discretion inherent in implementing the Constitution to evade its original letter or spirit in pursuit of the judge's own extraconstitutional preferences.

\section{TABLE OF CONTENTS}

INTRODUCTION . . . . . . . . . . . . . . . . . . . . . . . . . .

I. The Need For a Unified Theory: A Brief History of Originalism. 7

A. INTRODUCING THE TERM "ORIGINALISM" . . . . . . . . . . 7

B. ORIGINAL PUBLIC MEANING, NOT FRAMERS' INTENT . . . . . . . . . 9

C. THE INTERPRETATION-CONSTRUCTION DISTINCTION . . . . . . . 10

D. THE SCHISM AMONG ORIGINALISTS $\ldots \ldots \ldots \ldots \ldots \ldots \ldots \ldots . \ldots \ldots$

II. Fiduciary Government and Judicial Duty $\ldots \ldots \ldots \ldots \ldots \ldots \ldots$.

A. CONSTITUTING A FIDUCIARY GOVERNMENT . . . . . . . . . . . 18

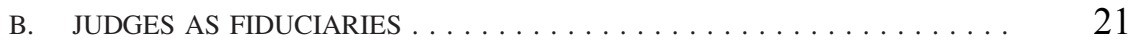

C. THE EXPRESS PROMISE OF EACH AND EVERY JUDGE . . . . . . . 23

III. The Judicial Duty Of Good-Faith Performance . . . . . . . . . . . . . 26

A. THE CONTRACTUAL DUTY OF GOOD-FAITH PERFORMANCE: THE

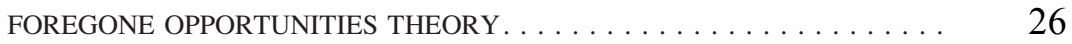

B. IMPLICATIONS FOR JUDICIAL DUTY: ADHERING TO THE SPIRIT OF THE TEXT . . . . . . . . . . . . . . . . . . . . . . . . . . 29

IV. Good-Faith Constitutional Construction . . . . . . . . . . . . 32

A. GUIDELINES FOR GOOD-FAITH CONSTRUCTION. . . . . . . . . . 33

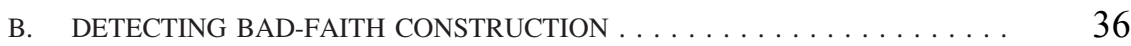

V. Examples of Good-Faith And Bad-Faith Construction . . . . . . . . 38

A. GOOD-FAITH CONSTRUCTION: THE REASONABLE REGULATION OF

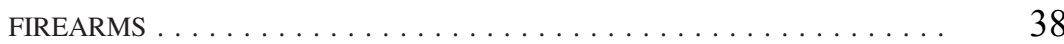

B. BAD-FAITH CONSTRUCTION: THE SUBSTANTIAL-EFFECTS DOCTRINE . 
VI. Objections To Good-Faith Construction $\ldots \ldots \ldots \ldots \ldots \ldots \ldots$.

A. DOES IT REVIVE THE OLD ORIGINALISM? . . . . . . . . . . . . 45

B. BUT WHAT ABOUT THE SUMMING PROBLEM? . . . . . . . . . . . . 48

C. WHY DISTINGUISH INTERPRETATION FROM CONSTRUCTION? . . . . 52

D. WILL THE SPIRIT LEAD JUDGES ASTRAY? . . . . . . . . . . . . . 52

Conclusion: A Unified Theory of Originalism ................. 54

\section{INTRODUCTION}

Interpretation differs from construction in that the former "is the act of finding out the true sense of any form of words; that is, the sense which their author intended to convey; and of enabling others to derive from them the same idea which the author intended to convey. Construction, on the other hand, is the drawing of conclusions ... which are in the spirit, though not in the letter of the text."-Justice Thomas M. Cooley ${ }^{1}$

I, __ , do solemnly swear (or affirm) that I will administer justice without respect to persons, and do equal right to the poor and to the rich, and that I will faithfully and impartially discharge and perform all the duties incumbent upon me as __ under the Constitution and laws of the United States. So help me God.-Federal Judicial Oath ${ }^{2}$

Constitutional originalism is defined by a commitment to the original meaning of the letter of the constitutional text. Our thesis is that originalism must be committed to the Constitution's original spirit as well — the functions, purposes, goals, or aims implicit in its individual clauses and structural design. We term this spirit-centered implementation "good-faith constitutional construction."

Originalism is the view that the meaning of the Constitution remains the same until it is properly changed, with an Article $\mathrm{V}$ amendment being the only proper method of revision. ${ }^{3}$ Originalists hold that: (1) the meaning of a provision of the Constitution was fixed at the time it was enacted (the "Fixation Thesis"); and (2) that fixed meaning ought to constrain constitutional decisionmakers today

1. Thomas M. Cooley, A Treatise on the Constitutional Limitations Which Rest upon the Legislative Power of the States of the American Union *38 (Bos., Little, Brown \& Co. $2 \mathrm{~d}$ ed. 1871) (emphasis added) (quoting Francis Lieber, Legal and Political Hermenutics 11 (William G. Hammond ed., St. Louis, F.H. Thomas \& Co. 3d ed. 1880)).

2. 28 U.S.C. $\$ 453$ (2012) (emphasis added).

3. The idea that originalism is a theory of constitutional change has been emphasized by Professor Stephen Sachs. See Stephen E. Sachs, Originalism as a Theory of Legal Change, 38 HARV. J.L. \& PuB. POL'Y 817 (2015). 
(the "Constraint Principle"). ${ }^{4}$ Over the past thirty years, originalist thought has evolved with respect to how the meaning of constitutional text was fixed.

The 1990s gave rise to the "New Originalism." Whereas the New Originalism contended that the meaning of constitutional text was fixed by the communicative content that it conveyed to the general public at the time of ratification-its "original public meaning," as famously proposed by Justice Antonin Scalia ${ }^{6}$ - the "old originalism" maintained that the meaning of the Constitution was fixed by the intentions of the Constitution's Framers.

Second, whereas many new originalists distinguished between two different activities - interpretation and construction - the old originalism tended to run these two activities together. Under New Originalism, "interpretation" means the activity of ascertaining the communicative content of the text. "Construction" means the activity of giving that content legal effect-typically (but not exclusively) by developing implementing rules through which the text will be applied in particular contexts. These implementing rules are not part of the communicative content of the text. ${ }^{8}$

Closely related to the second of these positions was a third: some New Originalists - including one of us — insisted that the usage of the terms "originalist" and "originalism" is properly confined to the activity of interpretation." According to this position, whatever one decides is the best method of giving legal effect to text, it cannot be originalist because that method will not be textually specified; and therefore, by definition, constitutional construction must be "nonoriginalist."

4. See Lawrence B. Solum, The Fixation Thesis: The Role of Historical Fact in Original Meaning, 91 Notre Dame L. Rev. 1, 6-7 (2015).

5. See Randy E. Barnett, An Originalism for Nonoriginalists, 45 Loy. L. Rev. 611, 626 (1999) ("[T]he ascendent New Originalism [is] based, not on original intent, but original meaning."); Keith E. Whittington, The New Originalism, 2 GeO. J.L. \& PuB. POL'y 599, 607-12 (2004).

6. Antonin Scalia, Common-Law Courts in a Civil-Law System: The Role of the United States Federal Courts in Interpreting the Constitution and Laws, in A MATTER OF INTERPRETATION: FEDERAL COURTS AND THE LAW 3, 47 (Amy Gutman ed., 1997).

7. Randy E. Barnett, Interpretation and Construction, 34 HARv. J.L. \& PUB. POL'y 65, 66 (2011); Lawrence B. Solum, The Interpretation-Construction Distinction, 27 Const. Comment. 95,96 (2010).

8. Although the texts of both the Ninth and Eleventh Amendments do provide rules of construction, these too need additional implementing rules to give them legal effect. We have in mind such implementing rules as the "presumption of liberty" for the former or "state sovereign immunity" for the latter.

9. Barnett, supra note 7, at 69 ("Originalism is not a theory of what to do when original meaning runs out."). We always agreed with Professor Lawrence Solum that originalist constitutional construction must conform to what Solum calls the "constraint principle" insofar as constitutional constructions must, at minimum, be consistent with the original meaning of the constitutional text. See Solum, supra note 4, at 8 ("All or almost all originalists can agree on a minimum level constraint: the doctrines of constitutional law and decisions in constitutional cases should be consistent with the original meaning - subject to limited and exceptional defeasibility conditions."). We propose here that the constraint on construction goes beyond the minimum of "consistency" and contend that construction can be originalist "all the way down." Thus, we affirm a version of what Solum has called "constraint as derivability." See Lawrence B. Solum, The Constraint Principle: Original Meaning and Constitutional Practice 24-25 (Mar. 24, 2017) (unpublished manuscript) https://papers.ssrn.com/sol3/papers.cfm?abstract_id=2940215 [https://perma.cc/ ABZ4-3WV8]. 
The postulate that constitutional construction is inherently nonoriginalist is mistaken and has led to unnecessary division among originalists. Most importantly, it may have led some originalists-including Justice Scalia_to reject the interpretation-construction distinction entirely. Originalist critics of the distinction have raised concerns that legitimating nonoriginalist methods of construction seriously undermines, if not entirely eliminates in practice, the "constraint" provided by originalist interpretation. ${ }^{10}$

We now believe that construction not only can but must be originalist. In this Article, we present an originalist theory of constitutional construction: good-faith constitutional construction. Good-faith constitutional construction seeks to implement the Constitution faithfully by ascertaining and adhering to the original functions of the constitutional text-its "spirit."

We hope that integrating both the letter and the spirit of the Constitution into a unified theory of originalism will not only unify modern originalists who have divided over the interpretation-construction distinction, but also unify original public meaning originalists with originalists who remain intentionalists. ${ }^{11}$ If "intentions" are understood as the functions of particular constitutional provisions or of constitutional design — as distinct from any subjective expectations concerning how particular provisions would be applied-we believe intentions should guide and constrain constitutional construction. ${ }^{12}$

We also believe that this unified theory of originalism helps distinguish originalism from some purposive versions of living constitutionalism. On our account, first comes the original meaning or letter of a provision (interpretation), and then, to implement that meaning, comes its original spirit or function (construction). That is, construction must neither precede interpretation nor give rise to a rule that contradicts original meaning.

10. See, e.g., Nelson Lund, The Second Amendment, Heller, and Originalist Jurisprudence, 56 UCLA L. REV. 1343, 1371 (2009) (expressing concern that construction-proponent Jack Balkin's approach "dissolves the distinction between originalism and living constitutionalism"); John O. McGinnis \& Michael B. Rappaport, Original Methods Originalism: A New Theory of Interpretation and the Case Against Construction, 103 Nw. U. L. REV. 751, 753 (2009) (arguing that "[c]onstitutional construction ... exacerbates agency costs, because it allows interpreters to employ discretion rather than requiring them to follow the guidance furnished by the original constitution-making process"); Richard S. Kay, Construction, Originalist Interpretation and the Complete Constitution, 19 U. PA. J. CONST. L. ONLINE 1, 3 (2017) ("[C]onstruction-as it appears in the current literature-leaves a wide discretion to officials and especially to judges employing it.”).

11. Prominent intentionalists include Larry Alexander, Saikrishna Prakash, and Richard Kay. See Larry Alexander \& Saikrishna Prakash, "Is That English You're Speaking?" Why Intention Free Interpretation Is an Impossibility, 41 SAN DIEGo L. REV. 967, 971 (2004); Richard S. Kay, Original Intention and Public Meaning in Constitutional Interpretation, 103 Nw. U. L. REv. 703, 704 (2009).

12. We do not mean to imply that Alexander, Kay, or Prakash understand intentions in this limited sense. Rather, all three scholars hold that texts mean what their authors intended them to mean. In our terms, their theories are primarily theories of the meaning of the letter of legal text. We thank Lawrence Solum for this observation. We suspect that, because the "spirit" is so closely related to the "letter" as sometimes to be indistinguishable — and because both are the subject of historical inquiry — this has induced some intentionalists to reduce both into the "letter." But this is only a hunch. 
The move that we are making preserves originalism as a distinctive theory. We maintain that the spirit of the Constitution cannot be used as a justification for updating or overriding the original meaning of its letter. Nor can the purposes or objectives of today's constitutional decisionmakers override the original functions of the text. ${ }^{13}$

Our analysis proceeds in the following steps. In Part I, we revisit the development of originalism and home in on a schism that has developed between originalists concerning the interpretation-construction distinction.

In Part II, we lay the constitutional foundations for our approach to construction. Drawing upon the pioneering scholarship of Robert Natelson, Gary Lawson, and Guy Seidman, we contend that judges were understood to be public fiduciaries at the time of ratification and to have duties that tracked those of private fiduciaries. We focus on two fiduciary duties: the duty to follow instructions and the duty to act in good faith. We argue that the voluntary assumption of office accompanied by the express oath to "support this Constitution" required by Article VI creates a fiduciary relationship that binds all government officials to follow instructions and act in good faith. ${ }^{14}$ We further argue that the oath imposes a moral and legal duty upon judges to engage in good-faith interpretation and construction.

In Part III, we draw upon Steven Burton's seminal "foregone opportunities" theory of good-faith performance to articulate our approach to constitutional construction. ${ }^{15}$ We argue that the duties of good faith in both contract law and fiduciary law are designed to thwart opportunism and that Burton's theory can serve as a framework for evaluating the good faith of our judicial fiduciaries. In the constitutional context, this framework constrains conscientious judges from using the discretion they have to devise implementing doctrine in a manner that undermines their oath to adhere faithfully to the text of the Constitution.

In Part IV, we set forth guidelines for good-faith constitutional construction. We argue that, in what Lawrence Solum has termed the "construction zone,"16 judges should identify the original functions of individual clauses and structural design elements to formulate rules that are consistent with the Constitution's letter and calculated to implement its spirit. ${ }^{17}$ Conversely, bad-faith construction consists of evading the Constitution's spirit and pursuing extralegal goals.

13. In future work, we intend to apply this conception of "good-faith constitutionalism" to the discretion exercised by legislators and executive branch officials.

14. U.S. CONST. art. VI, cl. 3.

15. See Steven J. Burton, More on Good Faith Performance of a Contract: A Reply to Professor Summers, 69 IowA L. REV. 497, 504-05 (1984); Steven J. Burton, Breach of Contract and the Common Law Duty to Perform in Good Faith, 94 HARV. L. REV. 369, 369 (1980).

16. See Lawrence B. Solum, Originalism and Constitutional Construction, 82 FordHAM L. ReV. 453, 458 (2013) (explaining that constitutional decision makers enter the construction zone when "the constitutional text does not provide determinate answers to constitutional questions").

17. Solum's influence on originalist theory and on the refinement of the interpretation-construction distinction has been enormous. For a sampling of his path breaking work, see Solum, supra note 16; Solum, supra note 7; Lawrence B. Solum, District of Columbia v. Heller and Originalism, 103 Nw. U. L. REV. 923 (2009) [hereinafter Solum, Heller and Originalism]; Lawrence B. Solum, Semantic 
In Part V, we use our theory of construction to evaluate constitutional doctrine. First, we highlight a good-faith construction of the right to keep and bear arms. We then turn to an example of bad-faith construction: the "substantial effects" doctrine, which has greatly extended congressional power to regulate the national economy.

In Part VI, we consider the objections that our theory is just old originalism repackaged; that, even if it is distinguishable from old originalism, it is vulnerable to similar criticism; that the interpretation-construction distinction is neither necessary nor useful; and that judges who seek the Constitution's spirit will be led astray.

\section{The Need For a Unified Theory: A Brief History of Originalism}

The history of originalism has been told many times. ${ }^{18}$ To demonstrate the need for a unified theory of originalism, however, we must first trace the development of originalism from the first appearance of the term "originalism" in constitutional law scholarship to the development and refinement of a defensible theory of originalism, and finally to a schism that has arisen within originalism that we aim to heal.

\section{A. INTRODUCING THE TERM "ORIGINALISM"}

Although we maintain that originalism as a method of constitutional interpretation is as old as the Constitution itself, the roots of originalism as a distinctive theory of interpretation can be traced back to 1980. That was the year Stanford law professor Paul Brest published his now-classic critique of originalism, The Misconceived Quest for Original Understanding, ${ }^{19}$ in the Boston University Law Review.

Brest was vague as to which scholars were the targets of his criticism, but judging from the frequency of his examples, Brest's primary target appeared to be Harvard researcher Raoul Berger, whose book Government by Judiciary was

Originalism (Univ. of Ill. Coll. of Law Pub. Law \& Legal Theory Research Paper Series, No. 07-24, 2008), http://papers.ssrn.com/sol3/papers.cfm?abstract id=1120244 [https://perma.cc/BJV7-U9SV]; see also Bryan H. Wildenthal, Nationalizing the Bill of Rights: Scholarship and Commentary on the Fourteenth Amendment in 1867-1873, 18 J. CONTEMP. LEGAL ISSUES 153, 261 (2009) ("I do not think anyone should write or speak above a whisper about originalist theory without confronting Solum's work."); Jeremy Kessler \& David Pozen, Some Legal Realism About Legal Theory (Columbia Pub. Law Research Paper No. 14-584, 2017), https://papers.ssrn.com/sol3/papers.cfm?abstract_id=3126412 [https://perma.cc/RC4H-WX9X] (describing Solum as a "leading originalist").

18. For sympathetic accounts by originalists, see Barnett, supra note 5, at 612-21; Vasan Kesavan \& Michael Stokes Paulsen, The Interpretive Force of the Constitution's Secret Drafting History, 91 GEO. L.J. 1113, 1134-48 (2003); Whittington, supra note 5, at 599-612; Solum, supra note 16, at 462-68. For a comprehensive overview by a historian, see JOHNATHAN O'NEILL, ORIGINALISM IN AMERICAN LAW AND POLITICS: A CONSTITUTIONAL History (2007). For a critical review of the literature, see Logan E. Sawyer III, Principle and Politics in the New History of Originalism, 57 AM. J. Legal Hist. 198, 198 (2017) ("We have gone from too few histories of originalism to too many ....").

19. Paul Brest, The Misconceived Quest for the Original Understanding, 60 B.U. L. REV. 204 (1980). 
published just three years earlier. ${ }^{20}$ A secondary target was Yale law professor Robert Bork. ${ }^{21}$ It was Brest who first dubbed Berger and Bork "originalists" and their approach "originalism" - a term that had not previously been used in the constitutional context: "By 'originalism' I mean the familiar approach to constitutional adjudication that accords binding authority to the text of the Constitution or the intentions of its adopters." 22 Brest contrasted originalism with "what I shall call 'nonoriginalism." ${ }^{23}$ Brest's article may well have provided the most influential labeling scheme in the history of constitutional law scholarship.

Brest conceded up front that, "[a]t least since Marbury, in which Chief Justice John Marshall emphasized the significance of our Constitution's being a written document, originalism in one form or another has been a key theme in the American constitutional tradition." ${ }^{24}$ But, nevertheless, Brest took aim at what he called "strict originalism," which he said was characterized by its "strict intentionalism." 25 "For the strict intentionalist, "the whole aim of construction, as applied to a provision of the Constitution, is ... to ascertain and give effect to the intent of its Framers and the people who adopted it.",26

Brest then identified the problem with strict intentionalism:

Strict intentionalism requires the interpreter to determine how the adopters would have applied a provision to a given situation, and to apply it accordingly. The enterprise rests on the questionable assumption that the adopters of constitutional provisions intended them to be applied in this manner. But even if this were true, the interpreter confronts historiographic difficulties of such magnitude as to make the aim practicably unattainable. ${ }^{27}$

For Brest, these "historiographical difficulties" arise by moving from the potentially ascertainable intentions of individual persons to deriving institutional intent from the myriad subjective intentions of all the members of the decisionmaking bodies that were responsible for the Constitution's adoption. Brest regarded this as a fool's errand. ${ }^{28}$ This general line of objection has come to be

20. See Raoul Berger, Government by Judiciary: The Transformation of the Fourteenth AMENDMENT (1977).

21. See Brest, supra note 19, at 223 (citing Robert Bork, Neutral Principles and Some First Amendment Problems, 47 InD. L.J. 1 (1971)).

22. Id. at 204.

23. Id. at 205 .

24. Id. at 204 .

25. Id.

26. Id. (quoting Home Bldg. \& Loan Ass'n v. Blaisdell, 290 U.S. 398, 453 (1934) (Sutherland, J., dissenting)).

27. Id. at 222-23 (emphases added). The astute reader will notice that "apply it accordingly" is actually describing constitutional implementation or construction, not the identification of meaning or interpretation. This is now commonly referred to as "original expected application." See Jack M. Balkin, Abortion and Original Meaning, 24 Const. Comment. 291, 292 (2007).

28. See Brest, supra note 19, at 212-13. 
called the "summing problem" 29 - that is, the problem of identifying and then somehow adding up or "summing" subjective intentions into collective intentions.

Only after Brest invented the term "originalism" did originalists adopt the label and defend it. ${ }^{30}$ Perhaps the earliest, most visible embrace was that of Edwin Meese III, who was President Ronald Reagan's Attorney General during Reagan's second term. In his address to the American Bar Association on July 9, 1985, Meese declared for "a jurisprudence of original intention.".31

Meese's address created quite a stir. At a conference at Georgetown University Law Center, Justice William Brennan took the opportunity to reply to the Attorney General. Echoing Brest, Brennan declared:

[I]t is far from clear whose intention is relevant - that of the drafters, the congressional disputants, or the ratifiers in the states - or even whether the idea of an original intention is a coherent way of thinking about a jointly drafted document drawing its authority from a general assent of the states. ${ }^{32}$

Although the battle lines were now publicly drawn, originalism's only theoretical explication remained Paul Brest's critical reconstruction. For this reason, Lawrence Solum has dubbed early writers like Berger and Bork "protoOriginalists." 33 But a theory of originalism was in the offing.

\section{B. ORIGINAL PUBLIC MEANING, NOT FRAMERS' INTENT}

Early discussion and development of originalism as a theory was initiated by the lawyers in the Meese Justice Department. In a span of four years, its ranks included such future law professors as Bradford Clark, Robert Delahunty, John Harrison, Gary Lawson, Nelson Lund, John Manning, John McGinnis, Richard Nagareda, John C. Nagle, Michael Stokes Paulsen, and Michael Rappaport. ${ }^{34}$

As these DOJ lawyers met in seminars and produced blue books on the original meaning of various constitutional provisions, they were addressed by thenCircuit Court Judge Antonin Scalia. Inspired in part by his antipathy towards the judicial use of legislative history in statutory interpretation, Scalia admonished

29. The term appears to have been first used in Robert Bennett, Originalist Theories of Constitutional Interpretation, 73 CORNELL L. REV. 355, 355 (1988).

30. The first academic defender of "originalism" after Brest took aim at it was Richard Kay. See Richard S. Kay, Adherence to the Original Intentions in Constitutional Adjudication: Three Objections and Responses, 82 Nw. U. L. REV. 226, 244 (1988).

31. See Edwin Meese III, U.S. Att'y Gen., Address before the American Bar Association (July 9, 1985), in The Great Debate: Interpreting Our Written Constitution 1, 9 (1986).

32. See William J. Brennan, Jr., The Constitution of the United States: Contemporary Ratification, 27 S. TEX. L. REV. 433, 435 (1986).

33. Solum, supra note 4 , at 3-4.

34. Also in the group were future Justice Samuel Alito; future judges Michael Luttig and Steven Markman; constitutional litigators Michael Carvin, Charles Cooper, and Theodore Olson; and lawyerauthor James Swanson. 
the DOJ attorneys to abandon their quest to discover the original intentions of the Framers and to pursue instead the original public meaning of the text. ${ }^{35}$

After they left the government in the 1990s, many of these lawyers began making important contributions to originalist scholarship as law professors. ${ }^{36}$ But it fell to Gary Lawson, first at Northwestern and then at Boston University, to expand upon Scalia's concept of original public meaning in a series of essays. ${ }^{37}$ Others followed suit. ${ }^{38}$

The shift from Framers' intent to original public meaning was responsive to Brest's critique of "strict intentionalism." Gone was the need to ascertain the collective intentions of decisionmaking bodies. This shift transformed what was, in practice, a counterfactual inquiry into what the Framers of the Constitution would have thought of some contemporary issue, into an empirical investigation of linguistic usage.

The move from Framers' intent to public meaning was the first big step in formulating a defensible theory of originalism. The next big step was taken, not by a judge or a law professor, but by a political scientist.

\section{THE INTERPRETATION-CONSTRUCTION DISTINCTION}

In 1999, Keith Whittington published two books in which he distinguished between (a) endeavoring to ascertain the communicative content of constitutional text and (b) making constitutional judgments when that endeavor fails to yield a single determinate answer-when the text "runs out." 39 The first of these activities he called constitutional interpretation, ${ }^{40}$ and the second constitutional construction..$^{41}$

35. Justice Antonin Scalia, Address Before the Attorney General's Conference on Economic Liberties in Washington, D.C. (June 14, 1986), in Original MEANING JuRISPRUdENCE: A SourCEBOOK 101, 103-04 (U.S. Dep't of Justice ed., 1987).

36. See, e.g., Steven G. Calabresi \& Saikrishna B. Prakash, The President's Power to Execute the Laws, 104 Yale L.J. 541 (1994); Michael Stokes Paulsen, The Most Dangerous Branch: Executive Power to Say What the Law Is, 83 GEO. L.J. 217 (1994).

37. See, e.g., Gary Lawson, On Reading Recipes . . . and Constitutions, 85 GEO. L.J. 1823 (1997) [hereinafter Lawson, On Reading Recipes]; Gary Lawson, The Rise and Rise of the Administrative State, 107 Harv. L. Rev. 1231 (1994); Gary Lawson, Proving the Law, 86 Nw. U. L. Rev. 859 (1992).

38. See works cited supra note 36. Prakash now identifies as an intentionalist. See Larry Alexander \& Saikrishna Prakash, Mother May I? Imposing Mandatory Prospective Rules of Statutory Interpretation, 20 CONST. COMMENT. 97, 100 (2003) ("[W] are intentionalists and believe that the meanings of words are those meanings intended by the author(s) or speaker(s).").

39. For a thorough exploration of the distinctions between determinacy, indeterminacy, and underdeterminacy, see Lawrence B. Solum, On the Indeterminacy Crisis: Critiquing Critical Dogma, 54 U. CHI. L. REv. 462 (1987). In brief, a legal question has a single determinate answer "if and only if the set of results that can be squared with the legal materials contains one and only one result." Id. at 473. A question is indeterminate "if and only if the set of results . . that can be squared with the legal materials is identical with the set of all imaginable results." Id. A question is underdeterminate "if and only if the set of results . . that can be squared with the legal materials is a nonidentical subset of the set of all imaginable results." Id.

40. See Keith E. Whittington, Constitutional Interpretation: Textual Meaning, Original INTENT, AND JUDICIAL REVIEW (1999).

41. See Keith E. Whittington, Constitutional Construction: Divided Powers And Constitutional MeAning (1999). 
Although unfamiliar to constitutional scholars-originalists and nonoriginalists alike - when Whittington advanced it, the interpretation-construction distinction can be found in constitutional theory as early as the 1830 s. $^{42}$ In a 1839 treatise, Legal and Political Hermeneutics, legal scholar Francis Lieber formally distinguished between interpretation and construction, defining "construction" as "the drawing of conclusions respecting subjects, that lie beyond the direct expression of the text, from elements known from and given in the text-conclusions which are in the spirit, though not within the letter of the text." 43

In 1868, Thomas McIntyre Cooley incorporated Lieber's distinction into a constitutional treatise that became highly influential in the late nineteenth century. Cooley was a professor at the University of Michigan Law School from 1859 to 1884 - serving as its dean from 1871 to 1883 - and the Chief Justice of the Michigan Supreme Court from 1864 to 1885. His A Treatise on the Constitutional Limitations Which Rest Upon the Legislative Power of the States of the American Union, was published the same year that the Fourteenth Amendment was ratified. ${ }^{44}$

In a chapter on the construction of state constitutions, Cooley explained that interpretation differs from construction in that the former "is the act of finding out the true sense of any form of words, that is, the sense which their author intended to convey, and of enabling others to derive from them the same idea

42. See LIEBER, supra note 1, at 44; see also Ralf Poscher, The Hermeneutic Character of Legal Construction, in LAW's HeRmeneutics: OTHER InVESTIGATIONS 207, 207 (Simone Glanert \& Fabien Girard, eds., 2017). See generally Greg Klass, Interpretation and Construction 1: Francis Lieber, NEW PRIVATE LAW: PROJeCt ON THE Foundations OF PRIVATE LAW (Nov. 19, 2015), http://blogs.harvard.edu/nplblog/2015/11/19/ interpretation-and-construction-1-francis-lieber-greg-klass/ [https://perma.cc/X4AH-MAXD]; Greg Klass, Interpretation and Construction 2: Samuel Williston, NEW PRIVATE LAW: PROJECT ON THE FOUNDATIONS OF PRIVATE LAW (Nov. 23, 2015), https://blogs.harvard.edu/nplblog/2015/11/23/interpretation-and-construction-2samuel-williston-greg-klass/ [https://perma.cc/3CWS-W2Q5]; Greg Klass, Interpretation and Construction 3: Arthur Linton Corbin, NeW Private LaW: Project on the Foundations of Private LaW (Nov. 25, 2015), http://blogs.harvard.edu/nplblog/2015/11/25/interpretation-and-construction-3-arthur-linton-corbin-greg-klass/ [https://perma.cc/AP7C-WZZS].

43. LIEBER, supra note 1 , at 44 (emphasis added). How did this distinction become lost and unfamiliar when it was delineated by one of the most eminent nineteenth century legal scholars and adopted in one of the most influential nineteenth century constitutional treatises? We can only speculate. One possibility: Lieber assumed that in some nontrivial number of cases there was "one true meaning" that could be discovered by judges through objective interpretation. See id. at 108. This view was subjected to devastating criticism in the early twentieth century by the realists. See, e.g., K.N. Llewellyn, The Constitution as an Institution, 34 CoLuM. L. REV. 1, 31-40 (1934) (arguing that judges read their own values into the texts they interpret). If that criticism is valid, there is no need to distinguish between interpretation and construction — all judicial decisionmaking takes place within the construction zone. We suspect that the realists found their indeterminacy in the construction zone and then attributed it to interpretation as well, but we have not examined their examples to establish this. We suspect further that the object of this move was to escape the constraints imposed by the letter of the text as part of their campaign against "formalism" in favor of doing "substantive justice." Collapsing the distinction helps advance this objective.

44. Cooley, a Treatise on the Constitutional Limitations Which Rest Upon the Legislative Power of the States of the American Union, (Bos., Little, Brown \& Co. 1868). 
which the author intended to convey." ${ }^{45}$ Construction, on the other hand, "is the drawing of conclusions respecting subjects that lie beyond the direct expressions of the text, from elements known from and given in the text; conclusions which are in the spirit, though not in the letter of the text."46

In addition to Lieber, Cooley relied on Bouvier's Law Dictionary:

Bouvier defines the two terms succinctly as follows: "Interpretation, the discovery and representation of the true meaning of any signs used to convey ideas." "Construction, in practice, determining the meaning and application as to the case in question of the provisions of a constitution, statute, will, or other instrument, or of an oral agreement." 47

According to Cooley, the need for construction arises from a number of sources.

The deficiencies of human language are such that if written instruments were always carefully drawn, and by persons skilled in the use of words, we should not be surprised to find their meaning often drawn in question, or at least to meet with difficulties in their practical application. But these difficulties are greatly increased when draughtsmen are careless or incompetent, and they multiply rapidly when the instruments are to be applied, not only to the subjects directly within the contemplation of those who framed them, but also to a great variety of new circumstances which could not have been anticipated, but which must nevertheless be governed by the general rules which the instruments establish. So, also, the different stand-points which diverse interests occupy incline men to take different views of the instruments which affect those interests; and from all these considerations the subject of construction is always prominent in the practical administration of the law. ${ }^{48}$

The interpretation-construction distinction was subsequently refined by contracts scholars, including Arthur Corbin, Edwin Patterson, and Allen Farnsworth. ${ }^{49}$ Corbin went beyond Lieber to maintain that any judicial activity which did not involve ascertaining the meaning of expressions or determining that a contract existed was not part of interpretation but was part of construction. ${ }^{50}$ Thus refined, the interpretation-construction distinction eventually made its way into the

45. Id. at $38 \mathrm{n} .1$ (quoting LIEBER, supra note 1, at 11).

46. $I d$. (emphasis added).

47. $I$. a 39 (quoting JoHn Bouvier, A LAW Dictionary, ADAPTED TO THE CONSTITUTION AND Laws of the United States of America, and of the Several States of the American Union (edition unknown)).

48. Id. at 38 .

49. See 3 Arthur Linton Corbin, Corbin on Contracts $\S 5$ 532-35 (1960 \& Supp. 1980); E. Allan Farnsworth, "Meaning” in the Law of Contracts, 76 YALE L.J. 939 (1967); Edwin W. Patterson, The Interpretation and Construction of Contracts, 64 CoLuM. L. REV. 833 (1964).

50. For a discussion of the differences between Lieber's and Corbin's approaches, see Lawrence A. Cunningham, Hermeneutics and Contract Default Rules: An Essay on Lieber and Corbin, 16 CARDOZO L. REV. 2225 (1995). 
Restatement of Contracts and continues to play a role in contracts scholarship and in guiding adjudication. ${ }^{51}$

Informed by his views of popular sovereignty, Whittington initially associated the activity of constitutional interpretation with the judiciary and the activity of constitutional construction solely with the "political" branches. In 1999, one of us_-Randy Barnett—articulated a somewhat different view. First in 1999 in An Originalism for Nonoriginalists, ${ }^{52}$ and later in 2004 in Restoring the Lost Constitution, ${ }^{53}$ Barnett contended that judges too needed to engage in constitutional construction when the original meaning of the text "runs out." 54 That is, when original meaning was insufficient to determine the outcome of a case or controversy, the judiciary needed to engage in constitutional construction to supplement original meaning. 55

Soon thereafter, echoing Corbin, Lawrence Solum clarified that, whereas constitutional interpretation was the activity of ascertaining the text's communicative content, constitutional construction was the activity of giving the text legal effect. ${ }^{56}$ Even if the communicative content of the text is "thick" enough for a constitutional decision maker to determine what is required in a particular setting, actually using that text to make a legally effective decision is an act of construction. If the text is sufficiently thick, however, the decision maker need not enter what Solum has termed the "construction zone" and develop a textually unspecified rule to resolve the matter at hand. ${ }^{57}$

The interpretation-construction distinction became the second component of a defensible theory of originalism. But the introduction of this distinction into originalist theory would also open a schism among originalists that persists to this day.

51. See Keith A. Rowley, Contract Construction and Interpretation: From the "Four Corners" to Parol Evidence (and Everything in Between), 69 Miss. L.J. 73 (1999); Solum, supra note 16, at 486-87 (citing cases deploying the distinction).

52. Barnett, supra note 5.

53. See Randy E. Barnett, Restoring the Lost Constitution: The Presumption of Liberty (2004); see also Solum, supra note 7; Solum, supra note 16.

54. See BARNETT, supra note 53, at 121-30. Whittington would soon accept this expanded vision of the activity of constitutional construction:

[C]onstitutional constructions, as distinct from constitutional interpretations, must be and are made by political actors in and around the elected branches of government. Perhaps they should also be made on occasion by judges, but in doing so, judges are engaging in a political and creative enterprise and cannot simply rely on the authority of interpreting the founders' Constitution.

See Whittington, supra note 5, at 612. The theory presented here takes issue with the claim that construction is necessarily "political." See BARNETT, supra note 53, at 122-24 (rejecting the claim that construction is inherently political).

55. Randy E. Barnett, Interpretation and Construction, 34 HARV. J.L. \& PuB. PoL'y 65, 69 (2011).

56. Lawrence B. Solum, Communicative Content and Legal Content, 89 Notre Dame L. ReV. 479, 488 (2013).

57. Solum, supra note 16 , at 458. Put still another way, whereas giving legal effect to any constitutional text requires constitutional construction, only when giving effect to underdeterminate text need one enter into the construction zone and adopt a textually unspecified rule of decision. 


\section{THE SCHISM AMONG ORIGINALISTS}

As explicated by Whittington, Barnett, and Solum, the interpretationconstruction distinction had a seemingly logical entailment. Because only constitutional interpretation was concerned with ascertaining the original communicative content of constitutional text, only interpretation could be originalist. Construction was not and could not be originalist:

According to the distinction between interpretation and construction, then, originalism is a method of constitutional interpretation that identifies the meaning of the text as its public meaning at the time of its enactment. The text of the Constitution may say a lot, but it does not say everything one needs to know to resolve all possible cases and controversies. Originalism is not a theory of what to do when original meaning runs out. ${ }^{58}$

Furthermore, whereas ascertaining the original communicative content of the text was an empirical inquiry into linguistic meaning, constitutional construction seemingly had little or no such empirical constraint. Therefore, the constraining "rule of law" benefits of originalism - indeed, of a written constitution-did not seem to carry over to constitutional construction. To the extent a clause was irreducibly ambiguous or vague, judges (and other constitutional decisionmakers) seemed to regain the relatively open-ended discretion that characterizes living constitutionalism, thereby undermining a rule-of-law commitment that unites all originalists.

Those concerned that the interpretation-construction distinction gives judges too much discretion have criticized the distinction in primarily two ways. First, some critics have simply denied the distinction exists. This was the tack taken by Justice Scalia and Bryan Garner in their 2012 book Reading Law. In that volume, Scalia and Garner contended that the interpretation-construction distinction was based on a linguistic misunderstanding. "[T]he noun construction answers both to construe (meaning 'to interpret') and to construct (meaning 'to build')," the authors explained, and "nontextualists have latched onto [this] duality of construction." ${ }^{59}$ But, they averred, "this supposed distinction between interpretation and construction has never reflected the courts' actual usage"-in legal practice, the terms are synonymous. ${ }^{60}$ Thus, "[f]rom the germ of an idea in the theoretical works of . . . Francis Lieber," they argued, has been "born, out of false linguistic association, a whole new field of legal inquiry." 61

As it happens, Cooley in the first edition of "Constitutional Limitations" included a footnote that anticipated this criticism:

58. Barnett, supra note 55, at 69 (emphasis added).

59. Antonin Scalia \& Bryan A. Garner, Reading Law: The Interpretation of Legal Texts 13 (2012).

60. Id. at 15. For a response to Scalia and Garner, see Solum, supra note 16, at 483-88.

61. SCALIA \& GARNER, supra note 59, at 13-14. 
In what we shall say in this chapter, the word construction will be employed in a sense embracing all that is covered by the two words interpretation and construction when used in their strictly accurate and technical sense. Their meaning is not the same, though they are frequently used as expressing the same idea. $^{62}$

Justice Cooley was right and Justice Scalia was wrong. Regardless of the labels used, ascertaining the communicative content of a text is a different activity than giving legal effect to that meaning. Although it is not interpretation, constitutional construction — call it implementation if you like-is unavoidable.

Indeed, it is because he lacked the interpretation-construction distinction in his toolkit that Justice Scalia took an unfortunate turn in his otherwise methodologically rigorous originalist opinion for the Court in District of Columbia v. Heller. ${ }^{63}$ As we will explain in Part IV, had he accepted the distinction, Justice Scalia would have been equipped to explain why textually unspecified doctrines were needed to apply the original meaning of "the right to keep and bear arms" to particular types of firearms, such as machine guns, or to particular persons, such as convicted felons. ${ }^{64}$ As it was, machine guns and convicted felons were presented as ad hoc exceptions to the Second Amendment right without any explanation at all. ${ }^{65}$

The second main criticism aimed at the interpretation-construction distinction is by those who accept the distinction in principle, but deny that it has much, if any, practical application. If construction begins only when original meaning ends, then the thicker the communicative content of the text, the less need there is to enter into the construction zone at all. ${ }^{66}$ Conversely, if original meaning is thin, the construction zone is vast and virtually all litigated constitutional cases may require recourse to textually unspecified rules of decision. Although Solum and Barnett have explained that the communicative content of the Constitution is much thicker than its bare semantic meaning, ${ }^{67}$ others have maintained that the Constitution's text is thick enough to eliminate the construction zone altogether.

Gary Lawson and Michael Paulsen have contended that interpretive presumptions which guide decisionmaking in the face of evidentiary uncertainty are a part of the text's original meaning. ${ }^{68}$ John McGinnis and Michael Rappaport have sought to thicken original meaning in two different ways. First, by contending

62. CoOley, supra note 44, at $38 \mathrm{n} .1$ (fourth emphasis added).

63. 554 U.S. 570 (2008).

64. Id. at 626-27.

65. For a critique of the ad hoc nature of this paragraph, see Lund, supra note 10.

66. This would still be construction, but it is not the kind of construction that those who are concerned about the interpretation-construction distinction are really worried about-their worry is about the construction zone and the discretion that it seems to afford decision makers. See supra note 10.

67. See, e.g., Lawrence B. Solum, Originalist Methodology, 84 U. CHI. L. REV. 269, 288-91 (2017) (discussing contextual enrichment of the sparse semantic content of the constitutional text).

68. See Gary Lawson, Dead Document Walking, 92 B.U. L. REv. 1225, 1226 (2012); Michael Stokes Paulsen, Does the Constitution Prescribe Rules for its Own Interpretation?, 103 Nw. U. L. REV. 857, 859 (2009). 
that the "original methods" of judicial decisionmaking are a part of the text's original meaning. ${ }^{69}$ Second, by claiming that the Constitution is written in what they call "the language of the law," which is thicker than the meaning that would be known to the general public. ${ }^{70}$

We can appreciate the concerns about judicial discretion that have been raised regarding the construction zone. If, as originalism critic Thomas Colby has put it, the original meaning of the Constitution is "sufficiently open-ended as to be incapable of resolving most concrete cases," and if there will be "multiple rules of decision that are each consistent with the original meaning of the vague or ambiguous constitutional command," judges embarking upon a construction project might seem to be adrift in an ocean of discretion. ${ }^{71}$ Loosely bounded judicial discretion ought to be deeply troubling to anyone who values the rule of law.

Further, it is of little practical benefit to judges to be told that they are free (within the boundaries set by thin semantic meaning) to articulate whatever rules of decision they deem to be consistent with their preferred normative theories. Judges do not have the time to consider how they might make the Constitution "the best it can be," so long as they stay within the bounds of a capacious normative framework, and they have lots of other things to think about that do not involve moral or political philosophy. ${ }^{72}$

A growing body of research supports the proposition that judges (like the rest of us) rely upon heuristics: mental shortcuts that simplify decisionmaking. ${ }^{73}$ Heuristics are not necessarily good or bad. Heuristics that are well-adapted to a given decisionmaking environment can better position decisionmakers to make accurate judgments than can more complex and effortful strategies. But maladaptive heuristics can produce systematic errors.

One way to safeguard against such errors is to provide judges with the tools to develop well-adapted heuristics. Thus, originalists who insist that entrance into the construction zone will inevitably occur in a nontrivial number of cases can address the concern that recognition of the interpretation-construction distinction

69. See McGinnis \& Rappaport, supra note 10, at 751.

70. John O. McGinnis \& Michael B. Rappaport, The Constitution and the Language of the Law 24 (Univ. of San Diego Sch. of Law Legal Studies, Research Paper No. 17-262, 2017), https://papers.ssrn. com/sol3/papers.cfm?abstract_id=2928936 [https://perma.cc/BC4Q-ZLME].

71. Thomas B. Colby, The Sacrifice of the New Originalism, 99 GEO. L.J. 713, 732 (2011).

72. See Ronald Dworkin, LAw's EMPIRE 248 (1986). The preeminent "moral reading" theorist today is James Fleming. James E. Fleming, Fidelity to Our Imperfect Constitution: For Moral REAdings And Against Originalism (2015).

73. The most influential article on heuristics in cognition was written by Amos Tversky and Daniel Kahneman. See Amos Tverskey \& Daniel Kahneman, Judgment Under Uncertainty: Heuristics and Biases, in Judgment Under Uncertainty: Heuristics And Biases 3, 3 (Daniel Kahneman, Paul Slovic \& Amos Tversky eds., 1982). For a variety of perspectives on the use of heuristics in legal settings, see generally HeuRISTICS IN THE LAW (Gerd Gigerenzer \& Christoph Engel eds., 2006). For evidence that judges rely on heuristic reasoning, see, e.g., Stephen M. Bainbridge \& G. Mitu Gulati, How Do Judges Maximize? (The Same Way Everybody Else Does-Boundedly): Rules of Thumb in Securities Fraud Opinions, 51 EMORY L.J. 83 (2002); Chris Guthrie et al., Inside the Bankruptcy Judge's Mind, 86 B.U. L. REV. 1227 (2006); Chris Guthrie et al., Inside the Judicial Mind, 86 CoRnELL L. REV. 777 (2001). 
exposes the citizenry to arbitrary judicial power, by developing and providing to judges a manageable and reliable methodology for disciplining constitutional construction. That is the goal of our project.

We agree that, because the original meaning of the text is broader than what bare semantic analysis yields, the construction zone is narrower than is sometimes thought. Modern originalist scholarship has revealed that many of the supposedly abstract and open-ended provisions of the Constitution have more definite and restricted meaning when contextually enriched. But because we continue to maintain that some decisionmaking within the construction zone is inevitable ${ }^{74}$ we approach this problem from the opposite direction by presenting a theory of constitutional construction that is constraining.

Terminologically, because we contend that this constraining approach to construction is "originalist," we are proposing that the label "originalist" can accurately be applied both to the activity of ascertaining the communicative content of the text and to the activity of giving legal effect to or implementing that meaning.

As a matter of lexicography, the use of the word "originalism" to describe an approach to construction that is concerned with original functions or purposes is entirely consistent with usage. Starting with Brest, the word "originalism" has been used to describe an approach that looks to the purposes, goals, and intentions of the Framers and Ratifiers. At a deeper level, the conceptual structure of originalism has always been concerned with origins: our approach focuses on the functions present at the time each constitutional provision was enacted. We reject the idea that the construction of any given constitutional provision should be guided by functions that were not present at the time of enactment, although certainly subsequent amendments can add new functions to the constitutional text. ${ }^{75}$

Our approach is based on the first principles of the Constitution itself and was hinted at in Barnett's early explication of constitutional construction:

74. See Solum, supra note 16, at 499-524 (discussing the ineliminability of the construction zone).

75. Can subsequent amendments alter the original spirit of previously-enacted provisions? Imagine the following amendment:

Henceforth, the First Amendment should be construed in a way that promotes equal participation in the political process, even if that means restricting campaign spending in ways that the Supreme Court wrongly held to violate the First Amendment in Citizens United v. FEC.

Under our approach, judges would be obliged to honor both the letter and spirit of this amendment, which does not repeal the First Amendment but is designed to change how it is construed. But this is an easy case. What about, say, the question of whether the Fourteenth Amendment alters the spirit of the Fifth Amendment, or whether the Nineteenth Amendment alters the spirit of the Fourteenth?

As Ryan Williams has put it, in cases where "the competing understandings of the two generations of Ratifiers [can]not be honored simultaneously, there [is] a fairly strong argument that the meaning of the later-enacted provision should control." Ryan C. Williams, The One and Only Substantive Due Process Clause, 120 YALE L.J. 408, 505 (2010). If the letter of the First Amendment can be repealed entirely by a subsequent amendment tailored to that end-and we have no reason to doubt that it can — surely its construction can be altered as well. But it's not clear why the original spirit of a subsequently enacted amendment should affect the construction of a previously enacted one absent affirmative evidence that it was designed to affect it. 
If the original meaning is too vague to provide a resolution of the case or controversy at issue, then (step 2) Choose a construction that yields a specific enough rule or doctrine to reach a unique resolution of the case at hand and future cases without violating the meaning ascertained in step 1. I would further contend that when construction is needed, adopt one that (a) is consistent with the original meaning of the terms at issue and yet (b) furthers the constitutional principles of, for example, separation of powers and federalism, and enhances the legitimacy of the lawmaking process. ${ }^{76}$

The approach we present here elaborates on step 2(b). It does so by adopting an approach similar to that of Gary Lawson and Guy Seidman (and by Robert Natelson before them), who have described what they call "the Fiduciary Constitution."77

\section{Fiduciary Government and Judicial Duty}

To borrow James Iredell's memorable description at the North Carolina ratifying convention, the American Constitution is "a great power of attorney."78 It bears the marks of a particular kind of legal document-one that creates a particular kind of relationship between "We the People" and their agents in government, who wield delegated powers on their behalf of their principals. Judges are no exception to a general principle that is central to understanding the Constitution's structure and content: the principle of fiduciary government.

\section{A. CONSTITUTING A FIDUCIARY GOVERNMENT}

Private fiduciary relationships ${ }^{79}$ are created when one person (the fiduciary) is entrusted with control or management of the assets or legal interests of another

76. BARNETT, supra note 53, at 128 (emphasis added). A similar suggestion was made by Lawrence Solum in response to Justice Scalia and Garner:

Scalia and Garner might allow for judicial decision in the construction zone that honors the Constraint Principle and resolves vagueness and irreducible ambiguity in ways that serve the purposes of particular constitutional provisions and the overall constitutional structure: of course, Scalia and Garner would limit the purposes to those fairly derived from text and history, and would exclude purposes warranted only by the moral and political beliefs of judges.

Solum, supra note 16, at 488 (emphases added).

77. See infra Part II.

78. 4 The Debates in the Several State Conventions on the Adoption of the Federal Constitution 148 (Jonathan Elliot ed., 2d ed. 1901) [hereinafter ElLiOT's DeBATES] (statement of Att'y Gen. Iredell) (“[T]his Constitution, where the people expressly declare how much power they do give, and consequently retain all they do not . . is a declaration of particular powers by the people to their representatives, for particular purposes. It may be considered as a great power of attorney, under which no power can be exercised but what is expressly given."); see also GARY LAWSON \& GUY SEIDMAn, "A Great Power Of AtTORnEy": Understanding the FiduCiary Constitution 3 (2017) (discussing Iredell's claim).

79. See generally LeOnARd I. Rotman, Fiduciary LAW (2005); J.C. Shepherd, The LaW of FidUCIARIES (1981); Robert Cooter \& Bradley J. Freedman, The Fiduciary Relationship: Its Economic Character and Legal Consequences, 66 N.Y.U. L. REV. 1045 (1991); Frank H. Easterbrook \& Daniel R. 
(the beneficiary) to promote the beneficiary's interests. ${ }^{80}$ One side of this relationship is characterized by the discretionary power that is placed in the hands of the fiduciary; the other side is characterized by the dependency and vulnerability of the beneficiary to injury from opportunistic behavior by the fiduciary. ${ }^{81}$

To prevent opportunism, ${ }^{82}$ the law imposes a set of rules $^{83}$ on fiduciaries. These rules include the duty to follow the beneficiary's instructions; the duty to take reasonable care and competently pursue the beneficiary's interests; the duty of loyalty, which includes a duty to act in good faith - that is, to honestly pursue the beneficiary's interests consistently with the original purposes of the entrustment; if there are a multiple beneficiaries, the duty of impartiality in considering and balancing their interests; and the duty to account to the beneficiary. ${ }^{84}$

Americans at the Founding understood the relationship between "government and governed" in fiduciary terms, influenced in this regard by their favorite political theorists. John Locke, whose influence upon Founding-era political philosophy has been widely noted, presented government officials as fiduciaries who wielded powers delegated to them by the people "with this trust, that they shall be govern'd by declared Laws" and referred to legislative power as a "fiduciary power to act for certain ends." 85 In their popular and highly influential series of essays, "Cato's Letters," published in the early 1720s, John Trenchard and Thomas Gordon described government as a "trust, which ought to be bounded

Fischel, Contract and Fiduciary Duty, 36 J.L. \& ECON. 425 (1993); L.S. Sealy, Fiduciary Relationships, 20 CAMBRIDGE L.J. 69 (1962); J.C. Shepherd, Towards a Unified Concept of Fiduciary Relationships, 97 LAw Q. REV. 51 (1981); Ernest J. Weinrib, The Fiduciary Obligation, 25 U. ToronTo L.J. 1 (1975).

80. See LAwSON \& SEIDMAN, supra note 78, at 13-27 (discussing the private law fiduciary background of the Founding era); Paul B. Miller, A Theory of Fiduciary Liability, 56 McGiLL L.J. 235 (2011) (discussing contemporary fiduciary theory).

81. By "opportunistic," we mean "self-interest seeking with guile," to borrow Oliver Williamson's widely-accepted definition. Oliver W. Williamson, THE ECONOMiC InSTITUTIONS OF CAPITALiSM: Firms, Markets, Relational Contracting 47 (1985).

Common fiduciary relationships include a trustee and beneficiary, guardian and ward, agent and principal, executor and deceased's estate, corporate officers and directors and shareholders, and partners in a partnership. Although these relationships are different in important respects, all of them involve a separation between the ownership and management or control of assets or legal interests; vulnerability to opportunism arising from that separation; and consequently high agency costs.

82. In economic terms, the fiduciary's control over the beneficiary's resources creates agency costs that cannot as a practical matter be eliminated through elaborate agreements ex ante or by continuous $e x$ post monitoring by the beneficiary. Agency costs can be understood as "the costs of opportunism and the costs of controlling opportunism." Robert Flannigan, The Economics of Fiduciary Accountability, 32 DEL. J. CORP. L. 393, 397 n.12 (2007). Fiduciary duties are designed to reduce those costs by aligning the incentives of the fiduciary with those of the beneficiary.

83. Although some fiduciary duties can be contractually overridden, others cannot — of particular importance for our purposes, a principal cannot authorize an agent to act in bad faith. See, e.g., UNIF. POWER OF ATtORnEy ACT § 114(a)(2) (UNIF. LAW COMM’n LAWs 2006); UNIF. TRUST CODE § 105(b)(2) (Unif. LAW COMM’n 2000); Restatement (ThiRd) OF Trusts $\$ 78$ cmt. c(2) (Am. LAW Inst. 2007); RESTATEMENT (THIRD) OF AGENCY $\$ \S 8.06(1)(a)(i),(2)(a)$ (AM. LAW Inst. 2006).

84. See Robert G. Natelson, Judicial Review of Special Interest Spending: The General Welfare Clause and the Fiduciary Law of the Founders, 11 Tex. Rev. L. \& PoL. 239, 255-62 (2007).

85. John Locke, Two Treatises of Government $\S \S 136,149$ (Peter Laslett ed., Cambridge Univ. Press 1965) (1690). 
with many and strong restraints" and stated that "[e]very violation ... where such violation is considerable, ought to meet with proportionable punishment."

Baron de Montesquieu's The Spirit of Laws, repeatedly cited by Federalists and Anti-Federalists alike, stated that citizens "entrusted" with public employment ought "to live, to act, and to think" for the sake of their fellow citizens alone. ${ }^{87}$ References to government officials as servants, agents, guardians, and trustees abound in Founding-era literature and in public debates over the Constitution. ${ }^{88}$ It is therefore unsurprising that, as Gary Lawson, Robert Natelson, and Guy Seidman have demonstrated, the Constitution was designed to establish a government "whose conduct would mimic that of the private-law fiduciary." 89

The Constitution's structure and content disclose its character as a fiduciary instrument. Like other eighteenth-century fiduciary documents, it begins with a preamble that states the purposes of the trust being established. ${ }^{90}$ It then delegates power to federal actors and institutions, as if to fiduciaries of "We the People." The Constitution refers to "public Trust" 92 and to public offices "of trust"; 93 Congress is empowered to enact measures that are "necessary and proper" for carrying delegated powers into execution, ${ }^{94}$ and to "lay and collect Taxes, Duties, Imposts, and Excises" to "provide for the . . . "general Welfare"; 95 and the President is required to "take Care that the Laws be faithfully executed." 96

86. 1 John Trenchard \& ThOMAs GORdon, CATO's LetTers 267 (Ronald Hamowy ed., Liberty Fund 1995) (1720).

87. Charles De Secondat, Baron De Montesquieu, The Spirit of Laws, in 38 GREAT Books OF THE Western World: Montesquieu/Rousseau 1, 31 (Thomas Nugent trans., Encyclopedia Britannica 1952) (1748).

88. See, e.g., The Federalist No. 14, at 63 (James Madison) (George W. Carey \& James McClellan eds., 2001) (in a republic, the people "assemble and administer [their government] by their representatives and agents"); THE FEDERALIST No. 46, supra, at 243 (James Madison) (referring to government officials as "agents and trustees of the people"); THE FEDERALIST No. 59, supra, at 310 (Alexander Hamilton) (emphasizing "guardianship" and "trust"); Letters from the Federal Farmer (Jan. 10, 1788), in 2 The Complete ANTI-Federalist 286, 289 (Herbert Storing ed., 2008) (calling legislators "agents" and "representatives").

89. Gary Lawson et al., The Fiduciary Foundations of Federal Equal Protection, 94 B.U. L. Rev. 415, 418 (2014); see also GARy LAWSON ET AL., The Origins of the NeCESSARy AND Proper Clause 68-70 (2010); Gary Lawson \& Guy Seidman, By Any Other Name: Rational Basis Inquiry and the Federal Government's Fiduciary Duty of Care, 69 FLA. L. REV. 1385, 1387 (2017); Robert G. Natelson, The Constitution and the Public Trust, 52 Buff. L. Rev. 1077, 1086 (2004); Robert G. Natelson, The Government as Fiduciary: A Practical Demonstration from the Reign of Trajan, 35 U. RICH. L. REV. 191, 193 (2001).

90. Robert G. Natelson, The Original Constitution: What it Actually Said and Meant 2728 (2010).

91. Lawson et al., supra note 89 , at 415 .

92. U.S. CONST. art. VI, cl. 3.

93. U.S. ConST. art. I, $\S 3$, cl. 7; id. art. I, $\S 9$, cl. 8; id. art. II, § 1, cl. 2 (“Office of Trust”).

94. Id. art. I, $\S 8$, cl. 18.

95. Id. art. I, $\S 8$, cl. 1.

96. Id. art. II, $\S 3$ (emphasis added). 
This organization and language sounds in eighteenth-century fiduciary law. ${ }^{97}$ Writes Natelson, it reveals a "purpose[] . . . to erect a government in which public officials would be bound by fiduciary duties to honor the law, exercise reasonable care, remain loyal to the public interest, exercise their power in a reasonably impartial fashion, and account for violations of these duties." 98

What does all this entail for the judiciary?

\section{B. JUDGES AS FIDUCIARIES}

There are compelling reasons to believe that the Founding generation regarded judges as subject to fiduciary norms. Founding-era writings presented judges as representatives of the people no less than legislators. Thus, Alexander Hamilton in Federalist 78 argued that judges are obliged to prefer the "intention of the people to the intention of their agents" in the legislature when those intentions conflicted. ${ }^{99}$ Shortly after the Constitution was ratified, a number of judges were impeached for violating fiduciary principles. For example, when Judge John Pickering was impeached in 1803 , he was charged with acting "contrary to his trust." 100

Lawson, Natelson, and Seidman contend that judges were understood by the ratifying public to be fiduciaries. But we also believe that the fiduciary model is normatively persuasive-that it captures the proper relationship between federal judges and the public today. As we will discuss, judges receive considerable discretionary power through a formal process that entails, among other things, a specific agreement to "support this Constitution." Because we are all vulnerable to judicial decisions that bring the government's coercive power to bear upon us, or that prevent the government's power from being used to our benefit, federal judges ought to be understood as fiduciaries, with

97. See LAwson \& SeIDMAn, supra note 78, at 7-13; Robert G. Natelson, The Legal Origins of the Necessary and Proper Clause, in The Origins of The Necessary ANd Proper Clause 52, 52-53 (2010); Robert G. Natelson, The General Welfare Clause and the Public Trust: An Essay in Original Understanding, 52 U. KAN. L. REV. 1, 50 (2003).

98. Robert G. Natelson, The Constitution and the Public Trust, 52 Buff. L. Rev. 1077, 1178 (2004).

99. The Federalist No. 78, supra note 88, at 404 (Alexander Hamilton).

100. 8 AnNALS OF CONG. 319-22 (1804). Pickering suffered from both alcoholism and insanity. See Emily Field Van TASSEl \& Paul Finkelman, ImPeachable OfFenses: A Documentary History FROM 1787 TO THE PRESENT 91-100 (1999). The first article of impeachment charged that the judge, "with intent to evade" the law, ordered a seized ship and two cables returned to "a certain Eliphalet Ladd, who claimed the same" without a prior appraisal and certificates from customs officers. 8 ANNALS OF CONG. 320 (1804). The second article charged that Pickering, "with intent to defeat the just claims of the United States," refused to hear the district attorney's witnesses and ordered the restoration of the ship and cables to Ladd. $I d$. at 321. Article three accused the judge of "wickedly meaning and intending to injure the revenues of the United States" by refusing the district attorney's appeal to the circuit court. Id. at 322. The fourth article described Pickering as being intoxicated at the trial and stated that "being a man of loose morals and intemperate habits" he lacked "essential qualities in the character of a judge." Id.; see also H. Lowell Brown, High CRimes AND MisdemeAnORS IN Presidential IMPeACHMENT 130-34 (2010). Although we take no position on the merits of the impeachment, we find it instructive that three of the charges sound in bad faith. 
corresponding duties. ${ }^{101}$

In constitutional interpretation and construction, the most relevant fiduciary duties are the duties to follow instructions and to act in good faith. Judges not only draw their power from Article III of the Constitution but are also required by Article VI to take an oath to "support this Constitution." 102 Guiding their conduct by "this Constitution" entails following the instructions given to them in the provisions of the Constitution that authorize and delimit their power.

Article III's text is sparse but thick with meaning. As Philip Hamburger has shown, the authorization of the "[t]he judicial power" incorporates a concept of the judicial office that was sufficiently understood during the Founding era as to render it unnecessary to spell out in great detail. ${ }^{103}$ At its core, judging was an office of independent judgment, undistorted by will. ${ }^{104}$ Judges were to decide cases before them in conformance with the law of the land, and not instantiate extralegal preferences. ${ }^{105}$ Judges' convictions concerning the law's justice could not overcome their duty to give effect to the law where its meaning was clear. ${ }^{106}$

In the early American republic, the duty of independent judgment had countermajoritarian implications. The principal threats to liberty in eighteenth-century America came from state legislatures and popular majorities that, as Hamburger explains, "repeatedly threatened the freedom of various racial, religious, political, and propertied minorities." 107 American judges came to be regarded as essential to the maintenance of the rule of law and the protection of individual rights. For that reason, the 1788 Constitution provided for a structurally independent federal judiciary—-staffed by judges who would serve only during "good Behaviour," and who would enjoy undiminished salaries (an attempt to forestall pecuniary threats to their independent judgment $)^{108}$ — whose purpose was, in Alexander

101. The scholar who has made the most of the oath in recent years is Richard Re, whose work we discuss infra notes 114-18.

102. U.S. CONST. art. VI, cl. 3

103. Philip Hamburger, LaW And Judicial Duty 148 (2008).

104. Id.

105. See id. at 148-59 (discussing need to resist influence of Crown officials seeking deference to executive power-externally imposed will); $i d$. at 173-78 (discussing need to resist influence of own political inclinations-internal will).

106. Id. at 55 (explaining that "judges at least by the sixteenth century came to recognize that they could pursue charitable suppositions about a statute's intent only when its intent was otherwise unclear").

107. Id. at 324. See also Michael J. Klarman, The Framers' Coup: The Making of the United States Constitution (2016) (documenting the Framers' "deep distrust of the people" and arguing that "nearly every substantive choice made in the Constitution" was informed by that distrust); GoRDON S. WoOd, The CREAtion OF THE AMERICAN Republic 1776-1787, at 409 (2d ed. 1998) (detailing how in the 1780s "Americans' inveterate suspicion and jealousy of political power, once concentrated almost exclusively on the Crown and its agents, was transferred to the various state legislatures," which had become "the institutions to be most feared").

108. See U.S. Const. art. III, $\S 1$. 
Hamilton's words, to "guard the Constitution and the rights of individuals." 109 Article III assures individuals who are confronted with assertions of government power, which they believe to be unlawful, that they need not resort to revolution to vindicate the rights that could be threatened by local legislatures no less than by a distant monarch.

\section{THE EXPRESS PROMISE OF EACH AND EVERY JUDGE}

In general, fiduciary relationships are voluntary - at least on the part of the fiduciary. ${ }^{110}$ As Gregory Klass has put it, "[O]ne does not become a trustee, an executor, a guardian, a corporate director, a joint venturer, an agent, an attorney, a teacher or a priest by accident."111

Although we maintain that it is a fiction to claim that each and every person subject to the jurisdiction of a government "tacitly" consents to that jurisdiction, ${ }^{112}$ each and every judge expressly consents to be bound by "this Constitution." In this way, the fiduciary relationship between federal judges and the rest of us arises through a formal promise. As Judge Frank Easterbrook has described it: "Like other judges, I took an oath to support and enforce both the laws and the Constitution. That is to say, I made a promise-a contract. In exchange for receiving power and lifetime tenure I agreed to limit the extent of my discretion." $" 113$

What is the content of that judicial promise? Article VI declares that " $[t]$ his Constitution ... shall be the supreme law of the land" and that "judicial officers, both of the United States and of the several states, shall be bound by oath or affirmation to support this Constitution." This same Constitution that is the "supreme law of the land" is the Constitution that "judicial officers" are bound by law and in conscience to support.

109. The Federalist No. 78, supra note 88, at 405 (Alexander Hamilton). Hamburger cautions against projecting such functional considerations into the minds of judges deciding cases. See HAMBURGER, supra note 103, at 610 ("[J]udges ordinarily assumed that they served the functions of enforcing the constitution and protecting liberty by doing their duty-by deciding in accord with the law of the land ...."). But "[i]t was understood that in doing their duty, the judges served broader constitutional functions." Id. at 323.

110. Certain fiduciary relationships do not require the beneficiary's consent - they are established through unilateral undertaking by the fiduciary. See Miller, supra note 80, at 253 (offering the guardianward relationship as an example).

111. Gregory Klass, What if Fiduciary Duties Are Like Contractual Ones?, in ConTRACT, STATUS, AND FidUCIARY LAw 101 (Paul B. Miller \& Andrew S. Gold eds., 2016).

112. See BARNETT, supra note 53, at 10-31 (critiquing claims for government authority based on "tacit consent"). But see RANDY E. BARNETt, OUR REPUBLICAN CONSTITUTION: Restoring THE LiBerTy AND SOVEREIGNTy of We THE PeOPle 73-78 (2017) (explaining the proper role of "presumed consent" in setting the boundaries of discretionary legislative power).

113. Frank H. Easterbrook, Textualism and the Dead Hand, 66 GeO. WASH. L. REv. 1119, 1122 (1998). Because one of us denies that contract law is based on "promise," we doubt that the formal promise of the oath constitutes a "contract" strictly speaking. See Randy E. Barnett, Contract Is Not Promise; Contract Is Consent, 45 SufFOLK U. L. REV. 647, 649-50 (2012). But we nevertheless insist that the judicial promise establishes a real and voluntary fiduciary relationship that is legally and morally binding. 
We emphasize "in conscience." Richard Re has observed that "[n]o handeither dead or alive-forces individuals to run for office, take the oath, or lead others to think that they will take 'the Constitution' seriously." ${ }^{114}$ Once officials do make such a promise, however, they are entrusted with power that they would not otherwise possess, a power that has moral implications.

Although a mere document cannot create binding moral obligations simply by virtue of its existence, officials entrusted with power over other people by virtue of a voluntary promise to adhere to the terms of that document are morally and legally bound to keep that promise. ${ }^{115}$ As Re has written, the oath "functions as a bridge between the document and the duty to obey it." ${ }^{116}$ More specifically, an oath to support the Constitution creates a morally binding promise "to adopt an interpretive theory tethered to the Constitution's text and history." 117 Were judges free to interpret the Constitution however they saw fit, in the service of whatever ends they deemed desirable, the oath would have little significance.

114. Richard M. Re, Promising the Constitution, 110 Nw. U. L. Rev. 299, 313 (2016); see also JosePh RAZ, THE AUTHORITY OF LAW 239 (2d ed. 2009) (“[A]n oath may impose a moral obligation to obey (e.g. when voluntarily undertaken prior to assuming an office of state which one is under no compulsion or great pressure to assume).”); STEPHEN Michael SHEPPARD, I Do Solemnly SweAR: THE Moral Obligations of Legal OfFicials (2009) ("Oaths are not taken alone. . . They are said aloud, in a manner that ensures at least the appearance of being voluntary. The oath represents an assurance that invites reliance upon those subject to the official's authority.").

115. Or what? How can "We the Principals" hold public officials to their fiduciary obligations? Unfaithful agents in the political branches may be removable during the next election cycle-what of judges, who enjoy life tenure during good behavior and who can be removed only with great difficulty, even if they consistently engage in bad behavior?

No response to this agency problem is likely to entirely satisfy. Our modest submission is that judges care about their reputations, and that providing their audiences with frameworks to evaluate their performance can increase the benefits of adopting those frameworks and the costs of deviating from those frameworks. For an exploration of how judicial desire for approval from salient personal audiences can affect judicial performance, see generally LAWRENCE BAUM, JUDGES AND THEIR Audiences: A PERSPECTIVE On Judicial BeHAVIOR (2006).

116. Re, supra note 114, at 308; see also Frank H. Easterbrook, What's So Special About Judges?, 61 U. Colo. L. REv. 773, 778 (1990) ("Judges may not derive the power to coerce others from the existence of legal rules and then say: 'Now that I have the power, I needn't follow the rules.' Rules are the source of the power being asserted.").

117. Re, supra note 114 , at 323-24. We agree with Re that the oath creates a morally binding promise. However, we depart from his contention that officials have a promissory obligation to adhere to the public's understanding of "the Constitution" at the time they take their oaths. Id. at 304. As Christopher Green has shown, indexical language-language whose reference shifts from context to context, like "this," "now," "here" and "that"- throughout the Constitution points toward a historical document. Thus, the oath taker's authority under "this Constitution" is contingent upon fidelity to that document. See Christopher R. Green, "This Constitution": Constitutional Indexicals as a Basis for Textualist Semi-Originalism, 84 Notre DAme L. ReV. 1607, 1612 (2009). For similar arguments, see Akhil Reed Amar, The Document and the Doctrine, 114 HARV. L. REV. 26, 33 (2000) ("With these words [in the Supremacy Clause], the Constitution crowns itself king; judges and other officials must pledge allegiance to the document."); Michael Stokes Paulsen, Does the Constitution Prescribe Rules for its Own Interpretation?, 103 Nw. U. L. REv. 857, 869 (2008) (““[T]his Constitution,' means, each time it is invoked ... the entire text of the written Constitution . . the document specifies the document as authoritative." (emphasis omitted)). 
The current text of the oath required of all federal officers makes explicit that the elevation of federal office triggers a duty to perform one's constitutional duties in good faith:

I, _ _ do solemnly swear (or affirm) that I will support and defend the Constitution of the United States against all enemies, foreign and domestic; that I will bear true faith and allegiance to the same; that I take this obligation freely, without any mental reservation or purpose of evasion; and that I will well and faithfully discharge the duties of the office on which I am about to enter. So help me God. ${ }^{118}$

The current text of the federal judicial oath also makes explicit the duty of good faith on the part of the judges and Justices.

I, __ , do solemnly swear (or affirm) that I will administer justice without respect to persons, and do equal right to the poor and to the rich, and that I will faithfully and impartially discharge and perform all the duties incumbent upon me as God. ${ }^{119}$ under the Constitution and laws of the United States. So help me

To say, however, that judges are fiduciaries who are duty-bound to exercise independent judgment and faithfully follow their constitutional instructions provides little guidance concerning (a) how judges are to interpret the Constitution, or (b) what they are to do in cases where they are unable to arrive at one determinate answer to a particular legal question solely by relying on the communicative content of the text. After all, even the Constitution's defenders have acknowledged the inherent imprecision in language and the impossibility of providing for every contingency in a written text. ${ }^{120}$

Originalists have a ready answer to the first question: judges are to ascertain the fixed communicative content of the Constitution's text. Originalists have yet to unify behind a framework for addressing the second question. ${ }^{121}$ We look to contract law-which, like fiduciary law, imposes a duty of good faith on powerexercising parties-for guidance here. Just as the predominant originalist approach to interpretation — original public meaning ${ }^{122}$ — closely resembles contract law's "objective theory of assent" as determined at the time of a contract's

118. 5 U.S.C. $\S 3331$ (emphasis added).

119. 28 U.S.C. $\$ 453$ (emphasis added).

120. See The Federalist No. 37, supra note 88, at 183 (James Madison).

121. Which is not to say that no one has theorized about the construction zone before. Jack Balkin identified eleven different kinds of arguments that have been invoked to guide construction. Jack Balkin, The New Originalism and the Uses of History, 82 FordHAM L. REV. 641, 655 (2013). Balkin's analysis is primarily descriptive rather than normative, however, and he does not provide a framework for evaluating particular constructions.

122. See John O. McGinnis \& Michael B. Rappaport, Originalism and the Good Constitution 123 (2013) (noting that public meaning originalism is "the predominant originalist theory"). 
formation, ${ }^{123}$ we believe the proper approach to constitutional construction resembles the contractual duty of good-faith performance.

\section{The Judicial Duty Of Good-Faith Performance}

In Part II, we explained why judges who voluntarily assume public office through an express oath to support "this Constitution" 124 thereby become fiduciaries who expressly bind themselves morally and legally to ascertain and "faithfully" give effect to the Constitution's original meaning. But how are judges to follow their constitutional instructions when the communicative content of the Constitution's text does not yield a single determinate answer, and they must exercise (textually bounded) discretion?

The same issue arises in contract law, when contractual text delegates discretionary powers to one of the parties - as they often do. How is this discretionary power to be exercised? In particular, how are ordinary contracting parties to be protected from the opportunistic abuses of such discretionary powers? Contract law has answered these questions by recognizing the duty of good-faith performance. This doctrine bars parties from using the discretion accorded them under the letter (the text) of the agreement to defeat the spirit (the original purpose) of the agreement.

In what follows, we will consider how a model of good-faith contractual performance illuminates the way judges ought to exercise their own discretionary power.

\section{A. THE CONTRACTUAL DUTY OF GOOD-FAITH PERFORMANCE: THE FOREGONE} OPPORTUNITIES THEORY

The duty to perform contracts in good faith has long been recognized as a general principle of contract law. ${ }^{125}$ Section 1-304 of the Uniform Commercial Code-adopted, with only minor variations, in forty-nine states and the District of Columbia to govern the sale of goods-stipulates that "[e]very contract or duty within [the Uniform Commercial Code] imposes an obligation of good faith

123. See RAndy E. BARnett, The Oxford Introductions to U.S. LAw: CONTRACts 68-74 (2010) (describing and explaining the rationale for the objective theory of assent).

124. Does it matter that the current form of the Article VI oath refers to "the Constitution" rather than "this Constitution"? It does not. If the current oath did not have the same referent as the text of Article VI-say, if it denoted "the understanding of the Constitution presently held by the oath-taker"- the current form of the oath would be constitutionally problematic, as it would facilitate an end-around the promise that the Constitution requires as a condition of deriving power from it. But there is no reason to think that the current oath has a different referent or that it is so understood by oath-takers. See Green, supra note 117, at $1645 \mathrm{n} .120$ (chronicling statements by officials spanning more than two centuries, all of which equate the oath "with the requirement of Article VI and the historic Constitution").

125. See E. Allan Farnsworth, Good Faith Performance and Commercial Reasonableness Under the Uniform Commercial Code, 30 U. CHI. L. REv. 666, 669-70 (1963) (tracing the duty of good-faith performance back to Roman law). 
in its performance and enforcement." ${ }^{126}$ Because it is implicit in every contract, the duty of good-faith performance cannot be waived (though the scope of performance can be more precisely defined in the contract). ${ }^{127}$ Importantly, as the Official Comment explains, "the doctrine of good faith merely directs a court towards interpreting contracts within the commercial context in which they are created, performed, and enforced, and does not create a separate duty of fairness and reasonableness which can be independently breached." 128

The duty of good-faith performance of a contract rests upon factual premises that are easily appreciated: people are not omniscient, they do not have endless time, they could not make agreements that provide for every contingency even if they desired to do so, and they would be discouraged from making agreements at all if they had to worry about every exercise of discretion being used to defeat the purposes for which they entered into agreements in the first place. ${ }^{129}$ Moreover, parties often contract to receive the benefit of specialized knowledge and judgment that they themselves lack. ${ }^{130}$ By necessity, that specialized knowledge must be drawn upon, and that judgment must be exercised at the discretion of the other party.

The duty of good-faith performance is a "gap-filling" doctrine that is calculated to preserve people's reasonable expectations in receiving the performance of the other party and the benefit of their bargains. The doctrine operates to thwart exercises of discretion that violate those reasonable expectations, even if that behavior does not breach any express contractual terms. ${ }^{131}$ That is, it operates to thwart opportunism-to prevent parties, as economist Oliver Williamson once put it, from "tak[ing] advantage of . . . the letter of the contract when the spirit of the exchange is emasculated." 132

Though entrenched in our law, the duty of good-faith performance has at times been bedeviled by uncertain formulations. ${ }^{133}$ To render the concept more precise,

126. U.C.C. § 1-304 (AM. LAW INST. \& UNIF. LAW COMM’N 2016).

127. U.C.C. § 1-102(3) (AM. LAW INST. \& UNIF. LAW COMM’N 2008) ("[T] faith, diligence, reasonableness and care prescribed by this Act may not be disclaimed by agreement but the parties may by agreement determine the standards by which the performance of such obligations is to be measured if such standards are not manifestly unreasonable.").

128. U.C.C. § 1-304 cmt. 1 (AM. LAW Inst. \& UnIF. LAW CoMm’n 2016).

129. See Randy E. Barnett, The Sound of Silence: Default Rules and Contractual Consent, 78 VA. L. REV. 821, 821-22 (1992).

130. Id. at 892 .

131. See Michael P. Van Alstine, Of Textualism, Party Autonomy, and Good Faith, 40 WM. \& MARY L. REV. 1223, 1256 (1999) ("[A] core function of the duty of good faith lies in imposing limitations on a party's exercise of a discretionary power to control an aspect of a contractual relationship after formation.").

132. WiLliamson, supra note 81 , at 62 .

133. See Randy E. Barnett, The Richness of Contract Theory, 97 Mich. L. REv. 1413, 1413-14 (describing how contracts scholars in the 1950s and 60s rejected "[a]ny effort to reduce the vast complexity of the real world of commercial practice to some verbal formula" and focusing in particular on the influential work of Robert Summers, who proposed a series of six categories of bad-faith performance and "explicitly denied that any more general conception of good faith was helpful or even possible"); see also Robert S. Summers, "Good Faith" in General Contract Law and the Sales Provisions of the Uniform Commercial Code, 54 VA. L. REv. 195 (1968). 
in 1980, Steven Burton presented a theory of the duty of good-faith performance of contracts that focused on contractually-delegated discretion. ${ }^{134}$ Surveying 400 cases in which courts expressly referred to good-faith performance, Burton contended that good faith in contract law operates as a means of ensuring that parties do not use the discretion accorded them under the terms of a contract to "recapture opportunities forgone upon contracting." 135

According to Burton, good-faith performance "occurs when a party's discretion is exercised for any purpose within the reasonable contemplation of the parties at the time of formation-to capture opportunities that were preserved upon entering the contract." 136 The doctrine of good-faith performance thus "directs attention to the opportunities forgone by a discretion-exercising party at formation, and to that party's reasons for exercising discretion during performance." 137 The identity of forgone opportunities is determined by focusing on the expectations of reasonable persons in the position of the dependent parties - the expectations as to benefits to be received by the promisee and expectations as to costs (foregone opportunities) to be borne by the promisee. ${ }^{138}$

Under Burton's approach, whether a particular discretion-exercising party acted for the purpose of recapturing foregone opportunities as objectively provided by the agreement is a question of subjective intent of the party exercising discretion. If a discretion-exercising party uses its control under the letter of the contract for the purpose of recapturing a foregone opportunity - even when the conduct is within the letter of the contract because the letter has granted that party discretion - the discretion-exercising party has acted in bad faith. Burton offered several illustrative examples from the case law, two of which involved contractual conditions where the satisfaction of those conditions was in the control of one party.

In Ide Farm \& Stable, Inc. v. Cardi, a contract for the sale of land was conditioned on the buyer's obtaining financing. ${ }^{139}$ The buyer did not go through with the deal, claiming an inability to obtain financing. ${ }^{140}$ The seller sued, claiming that the buyer had failed to perform in good faith. ${ }^{141}$ The evidence indicated that the buyer had approached four banks in the hopes of obtaining financing but was refused because of a tight money market. ${ }^{142}$ In this case, wrote Burton, "The reason for the buyer's failure was indeed the very one that induces the typical financing condition in land sale contracts" and thus the "buyer's

134. Steven J. Burton, Breach of Contract and the Common Law Duty to Perform in Good Faith, 94 HARV. L. REV. 369, 373 (1980).

135. Id.

136. Id. (emphasis added).

137. Id. (emphasis added).

138. Id. at 387.

139. 297 A.2d 643, 643-44 (R.I. 1972).

140. Id.

141. Id. at 645.

142. Id. 
discretion [in declining to accept financing at the proffered terms] ... was exercised in good faith in light of the purpose that parties normally have in mind in so conditioning a promise to buy land." 143

Burton contrasted Cardi with Fry v. George Elkins Co., which involved a sale of a residential home that was conditioned on the buyer securing financing at a specified rate. ${ }^{144}$ The buyer was informed at the time of the formation of the contract that he could not obtain such financing from a bank, but that it could probably be obtained from a particular mortgage company that already had a substantial loan on the property. ${ }^{145}$ Nonetheless, the buyer only approached banks and made no application or inquiry of the mortgage company. ${ }^{146}$ The evidence indicated that the buyer had lost all interest in the house and had decided to move to Hawaii ${ }^{147}$ — a reason decidedly "outside the normal reasons for so conditioning a promise to buy a house," and which was thus grounds for concluding that the buyer had subjectively "sought to recapture an opportunity foregone upon entering the contract." 148

Although it is often difficult to determine whether a party has exercised discretion for the purpose of recapturing a forgone opportunity, Burton's theory focuses judicial attention in the right place: whether discretionary power has been used to undercut the purpose for which discretion was given. Burton's theory also provides useful methods of evaluation, assessing exercises of discretion with reference to the parties' reasonable expectations at the time of the contract's formation and evidence that one party sought to evade or defeat those expectations.

\section{B. IMPLICATIONS FOR JUDICIAL DUTY: ADHERING TO THE SPIRIT OF THE TEXT}

We maintain that judges are fiduciaries, not ordinary contracting parties, and fiduciary relationships are not the same as ordinary contractual relationships. Yet, as fiduciary law scholar D. Gordon Smith, drawing upon Burton's theory, has observed, the fiduciary duty of good faith and the contractual duty of good faith are directed at a common evil: opportunism arising from discretion and vulnerability. Smith explains:

Fiduciary duty and the duty of good faith and fair dealing both exist because contracts are less than complete. In fiduciary relationships, discretion provides the fiduciary with the opportunity to expropriate value from the beneficiary; in contractual relationships, discretion provides one contracting party with the opportunity to "recapture opportunities forgone at formation." 149

143. Burton, supra note 134 , at 402 (emphasis added).

144. 327 P.2d 905, 906 (Cal. Dist. Ct. App. 1958).

145. Id.

146. Id. at 907.

147. Id. at $906-07$.

148. Burton, supra note 134, at 402.

149. D. Gordon Smith, The Critical Resource Theory of Fiduciary Duty, 55 VAND. L. REV. 1399, 1491 (2002) (quoting Burton, supra note 134, at 387). 
The common evil of opportunism that both the contractual and fiduciary duties of good faith are designed to thwart, taken together with Burton's specific focus on the opportunistic abuse of discretion under the letter of contracts, suggests the utility of Burton's forgone opportunities theory as a means of guiding constitutional construction.

Having said this, we stress that constitutions function as directives to government actors that are given on behalf of the people; constitutions are not contracts. ${ }^{150}$ An assessment of whether a government action was made for the purpose of reclaiming an opportunity that was forgone at the time a judge or other constitutional actor took an oath to obey the Constitution must be assessed differently than we assess the good faith of a limited set of contracting parties.

Where Burton's approach to the good faith performance of contracts looks to evidence of the subjective intent of a party to reclaim an opportunity that was objectively forgone, we favor an objective approach to ascertaining the good faith of governmental actors. As we will explain, whether or not an action was performed by a government agent in bad faith is a conclusion that results from an inquiry into the objectively assessed fit between the means adopted and the ends that are within the proper scope of a constitutional actor's powers. If the meansend fit is too attenuated, we can then conclude that the action was taken for the purpose of achieving other ends.

We do not favor inquiring directly into the motives of government officials to assess whether their actions were taken in good faith. But we should not blink the fact that constitutional actors often act for purposes that they forewent when receiving power in return for their oaths. A realistic consciousness of this fact justifies a degree of critical skepticism when assessing meansends fit.

Judges receive their power from the letter of a written instrument and by necessity enjoy a great deal of discretion, owing to the nature of the instructions given them-instructions which often lack the linguistic precision to yield determinate answers in cases that judges are duty-bound to decide. ${ }^{151}$ That power is delegated to judges by the people on the basis of their specialized knowledge of the law and judgment in deciding cases.

As with contractual discretion, judicial discretion can be abused. The people are vulnerable to opportunistic judicial behavior that can threaten their liberty, their property, and even their lives. Just as contracting parties can use their

150. See BARNETT, supra note 53, at 11-32 (explaining the differences between contracts and constitutions).

151. Indeed, Burton appreciated how his theory could serve as a means of guiding the exercise of judicial discretion, elaborating a comprehensive theory of good-faith adjudication in his 1992 book, Judging in Good Faith — albeit without advocating any particular theory of constitutional interpretation. Steven J. Burton, Judging In Good FAith (1992). 
contractual discretion in bad faith to undermine the "spirit" of the contract-its originally understood purpose or purposes - so too can fiduciaries abuse the discretion they are delegated to violate the purposes for which the fiduciary relationship was created.

What, then, is the spirit of the Constitution? At common law and in eighteenth-century America, the distinction between the linguistic meaning of a provision of a legal instrument and that instrument's fundamental purpose(s) or function(s) - whether a contract or a constitution - was expressed through a Christian trope: the distinction between the "letter" and the "spirit."152 Although the letter was ordinarily sufficient to resolve a given question, where the letter was obscure and judges confronted a need to choose, judges followed the spirit of the text.

An instructive example: When Edmund Pendleton, then President of the Virginia Court of Appeals, gave his opinion in the 1782 case of Commonwealth $v$. Caton, he said that because "[t]he language of the clause [of the Virginia Treason Act] ... admits of both the constructions mentioned by the attorney general," the choice of constructions should be "decided according to the spirit." ${ }^{153}$ Revealingly, Pendleton stated that he "prefer[red] the first, as most congenial to the spirit, and not inconsistent with the letter, of the constitution." 154

In this respect, Pendleton, like many American judges, ${ }^{155}$ followed Sir William Blackstone, who wrote that "the most universal and effectual way of discovering the true meaning of a law, when the words are dubious, is by considering the reason and spirit of it." ${ }^{156}$ The spirit of the law was considered to be part of the law. ${ }^{157}$

152. HAMBURGER, supra note 103, at 54.

153. 8 Va. (4 Call) 5,19 (1782).

154. Id.

155. See Robert G. Natelson, The Founders' Hermeneutic: The Real Original Understanding of Original Intent, 68 Онго Sт. L.J. 1239, 1251-53 (2007) (noting that reliance upon the "spirit," "sense," "meaning," or "reason" of an enactment "for purposes of documentary construction—sometimes even at the expense of the literal wording-reflected the norm in Anglo-American jurisprudence").

156. 1 William BlaCKSTONE, COMMENTARIES *61.

157. Consider a much-quoted passage by Edmund Plowden, among the most highly regarded legal authorities in England and America and often cited by American judges:

[I]t is not the words of the law, but the internal sense of it that makes the law, and our law (like all others) consists of two parts, viz. of body and soul, the letter of the law is the body of the law, and the sense and reason of the law is the soul of the law, quia ratio legis est anima legis. ["For the reason of the law is the soul of the law."] And the law may be resembled to a nut, which has a shell and a kernel within, the letter of the law represents the shell, and the sense of it the kernel, and as you will be no better for the nut if you make use only of the shell, so you will receive no benefit by the law, if you rely only upon the letter, and as the fruit and profit of the nut lies in the kernel, and not in the shell, so the fruit and profit of the law consists in the sense more than in the letter.

Eyston v. Studd (1574) 2 Plowden 459, 465, 75 Eng. Rep. 688, 695 (KB) (reporter's commentary). For Founding-era American citations to Plowden, see Natelson, supra note 155, at 1253 n.64. 
The distinction between letter and spirit-and recourse to the spirit (only) upon failure of the letter-captures an enduring truth. The Constitution's provisions, like the Constitution as a whole, are calculated to perform particular functions, and they would be without value if they did not do so. Truly understanding and applying the text may require an understanding of those functions. ${ }^{158}$ Lacking certainty about how to resolve a given case on the basis of the Constitution's linguistic meaning alone, judges must make a decision on the basis of some reason. To formulate a rule with reference to the function-or functions - that a relevant provision is designed to perform is not a matter of making the law "the best it can be" but giving effect to the law as best one can. A judge who decided a case on the basis of a reason that cannot be grounded in original functions-however normatively appealing that might seem-would be departing from the law entirely. ${ }^{159}$

To summarize: upon taking their oath, our judicial agents receive discretionary power. With this judicial power comes the corresponding duty to follow the instructions in "this Constitution" in good faith. To do so, judges must forgo the opportunity to act on the basis of anything but the letter and the spirit of the law. They must act not only consistent with the letter of the instrument from which they draw their power, but they must also not use their discretion under that instrument to pursue extralegal goals. Where the letter of the Constitution is unclear, judges must turn to the law's spirit.

\section{Good-Faith Constitutional Construction}

No theory of constitutional interpretation or construction can prevent federal judges from acting opportunistically if those judges do not value adherence to rules that are distinguishable from their preferences; ${ }^{160}$ do not care about how they are regarded by their colleagues and professional peers, ${ }^{161}$ and do not take their oath to the written Constitution of the United States seriously. ${ }^{162}$ But by

158. See Lawrence B. Solum, Communicative Content and Legal Content, 89 Notre Dame L. REV. 479, 500 (2013) (explaining that "the public context may include facts about the general point or purpose of the provision (as opposed to, the 'intention of the author'), and those facts may resolve [textual] ambiguities").

159. We recognize that judges may have difficulty identifying even one among several functions of a given provision or determining whether one function rather than another is more contextually relevant and should be given priority, given scarce time and research capacity. Our point is normative, not epistemic: judges should seek, identify, and use the original functions to guide their implementation of the original meaning of the text.

160. But see generally Michael A. Bailey \& Forrest Maltzman, The Constrained Court: Law, Politics, And The Decisions Justices MaKe (2011) (adducing evidence that legal factors influence judicial behavior as well as ideological factors).

161. But see generally Lawrence Baum, Judges And Their Audiences: A Perspective on JUDICIAL BEHAVIOR (2006) (adducing evidence that judges' desires for good reputations influence their behavior).

162. But see generally LeE EPSTEIn, William M. LANDES \& Richard A. Posner, The BeHAVior of Federal Judges: A Theoretical and Empirical Study of Rational Choice (2013) (adducing evidence that judges "audition" for higher office). 
articulating guidelines for how judges are to engage in good-faith construction and thereby enabling observers to monitor construction and identify opportunistic abuses of judicial discretion, we might make it more likely that (1) that good-faith construction will take place, and (2) bad-faith construction will be critically examined, censured, and discouraged.

\section{A. GUIDELINES FOR GOOD-FAITH CONSTRUCTION}

It bears emphasizing that, although constitutional construction necessarily takes place every time constitutional text is given legal effect, judges need notindeed, should not-enter into the construction zone in every constitutional case. The communicative content of terms that appear to be "thin" and therefore require entrance into the construction zone may be considerably "thicker" after careful empirical work. The original public meaning of seemingly open-textured provisions can be much more precise once their contextually enriched meaning is revealed by rigorous research.

For example, the original meaning of "recess" in the Recess Appointments Clause refers to the period between "sessions" of Congress, once context is taken into account. ${ }^{163}$ "Commerce . . among the several states" encompasses activity of particular kinds: the trade, exchange and transportation or movement of things. ${ }^{164}$ The Eighth Amendment's ban on "cruel and unusual punishment" forbids cruel innovation in punishment—specifically, punishments that are unjustly harsh in light of longstanding common-law practice. ${ }^{165}$

The attempt by originalists to recapture the more determinate thicker meaning of these and other clauses is in its relative infancy. Despite the public prominence of constitutional originalism, the number of originalist scholars has been few (indeed, almost miniscule if compared to the numbers of living constitutionalists) — and not enough given the importance of the task. Work on rigorous originalist methodology and the development of best practices for originalist scholarship is recent. ${ }^{166}$ Important tools, such as corpus linguistics, have only just been introduced. ${ }^{167}$

163. See Michael B. Rappaport, The Original Meaning of the Recess Appointments Clause, UCLA L. REV. 1487, 1487 (2005).

164. See Randy E. Barnett, The Original Meaning of the Commerce Clause, 68 U. CHI. L. Rev. 101, 101 (2001).

165. See John F. Stinneford, The Original Meaning of "Cruel”, 105 GEO. L.J. 441, 441 (2017); John F. Stinneford, The Original Meaning of "Unusual": The Eighth Amendment as a Bar to Cruel Innovation, 102 Nw. U. L. REv. 1739, 1745-46 (2008).

166. See Solum, supra note 67, at 288-91.

167. See James C. Phillips, Daniel M. Ortner \& Thomas R. Lee, Corpus Linguistics \& Original Public Meaning: A New Tool to Make Originalism More Empirical, 126 YALE L.J.F. 21, 21 (2016); Lawrence M. Solan, Can Corpus Linguistics Help Make Originalism Scientific?, 126 YALE L.J.F. 57, 57 (2016); Lee J. Strang, How Big Data Can Increase Originalism's Methodological Rigor: Using Corpus Linguistics to Reveal Original Language Conventions, 50 U.C. DAvis L. Rev. 1181, 1202 (2017). 
Further, as Gary Lawson has observed, the early originalists-like Berger and Bork-were moral readers. ${ }^{168}$ They were primarily focused on "judges, democracy, constraint, and authority," not on "meaning, language, and communication." 169 The empirical turn in originalism-originalism's shift from (as Lawson puts it) an "intellectual rather than political enterprise"-is quite recent. ${ }^{170}$

Once enriched, the seemingly vague or ambiguous language of the Constitution may be rendered precise enough to enable judges to arrive at many more answers to interpretive questions that, if not certainly correct, are more plausible than any competing answers. ${ }^{171}$ When, however, a determinate answer cannot be ascertained through interpretation, judges must enter the construction zone. A rule must be applied-either a previously formulated rule or a new one. We hold that that rule must be informed by the Constitution's original spirit.

Just as discovering the "spirit of the deal" requires an investigation into "the commercial context in which [a contract is] created," Constitution's various clauses and structural design entails investigation into the context in which they were enacted. This is a familiar task for originalists- the inquiry into the law's spirit is no less grounded in empirical facts than inquiry into the law's letter. ${ }^{173}$ Constitutions, statutes, and contracts are products of human design, and - as we will elaborate - one need not read minds to determine what they are designed to do. ${ }^{174}$ The Constitution was the result of a careful, if often contentious, "design process." Each provision and structural design element was crafted for a reason or reasons. We discover these reasons by examining how the Constitution's various components interact with one another, as well as by consulting what was said about them both in public and in private.

Judges do, however, need to take care to properly identify the level of abstraction at which the function of a provision or design element should be characterized, just as they must take care to properly identify the level of abstraction at which to understand particular words. John McGinnis and Michael Rappaport

168. See Gary Lawson, Reflections of an Empirical Reader (or: Could Fleming Be Right This Time?), 96 B.U. L. REv. 1457, 1472 (2016).

169. Id. We suspect this was because they were engaged in constitutional construction or application, not interpretation.

170. Id. at 1473 .

171. See Gary Lawson, Evidence of the Law: Proving Legal Claims 75 (2017) (arguing that a legal proposition "is deemed correct if it is better, meaning more plausible, than its available alternatives").

172. U.C.C. § 1-304 cmt. 1 (Am. LAW INST. \& UNIF. LAW Comm’N 2016).

173. For a valuable illustration, consider Justice Scalia's deep-dive into English common-law history -including case reports, legal commentaries, and petitions responding to perceived abuses - to identify "the principal evil at which the Confrontation Clause was directed" in Crawford v. Washington. 541 U.S. 36, 50 (2004).

174. See Richard A. Posner, Legal Formalism, Legal Realism, and the Interpretation of Statutes and the Constitution, 37 CASE W. RES. L. REv. 179, 196 (1986) ("A document can manifest a single purpose even though those who drafted and approved it had a variety of private motives and expectations."). 
have rightly warned about the dangers of the "abstract meaning fallacy"concluding that constitutional language has an abstract meaning without sufficiently considering the alternative possibilities. ${ }^{175}$ Judges must be equally wary of settling upon abstract purpose or function without closely investigating historical sources, with an eye toward capturing those functions that the Framers, Ratifiers, and members of the public understood particular provisions to serve.

Judges should then specify a construction — an implementing doctrine ${ }^{176}$ - that resolves the case at hand in a manner that is consistent with the relevant original function, and susceptible of application to future cases of a similar kind. A "rule" which applies in one case only is not a rule at all. Nor is a rule set forth without explanation likely to equip judges to effectuate a provision in future cases. Once derived and sufficiently explained, however, a construction can stand on its own. In future cases, judges need only explain why and how a construction applies and then apply it. They need not continually revisit how that construction facilitates the original function or spirit of the text.

The application of such constructions is what we call "constitutional law." Of course, as preexisting doctrines meet new and unanticipated circumstances, these implementing rules of constitutional law may have to be adjusted and refined to fit the functions the textual provisions were adopted to perform. That, indeed, is just how the common law of contract was developed over the centuries. ${ }^{177}$

Good-faith interpretation and construction thus consists in three separate steps:

(1) Make a good-faith effort to determine the original meaning of the text of the relevant provision and to resolve the case on the basis of the letter.

(2) Failing this, identify the original functions or spirit of the provision, and

(3) Formulate a rule to be followed in the case at hand and in the future that is

(a) consistent with the letter and

(b) designed to implement the original functions of

(i) the provision at issue or, failing that,

(ii) the structure in which the provision appears or, failing that,

(iii) the Constitution as a whole.

175. See John O. McGinnis \& Michael B. Rappaport, The Abstract Meaning Fallacy 2 (Northwestern Pub. Law, Research Paper No. 11-67, 2011), http://papers.ssrn.com/sol3/papers.cfm?abstract_id= 1959668 [https://perma.cc/PX4M-9SKR].

176. See generally RICHARD H. FALLON, JR., IMPLEMENTING THE CONSTITUTION (2001) (discussing the Court's implementation strategies for enforcing constitutional values).

177. See Randy E. Barnett, The Structure of Liberty: Justice and the Rule of Law 109-32 (2d ed. 2014) (identifying the evolutionary nature of the common-law decision process as a discovery mechanism). See generally A.W.B. Simpson, A History of the COMMON LAW OF CONTRACT (1987). 
Each step must be performed candidly and carefully, explaining why the implementing rule is consistent with the spirit of the Constitution, setting forth the rule clearly and concisely, and modeling its proper application.

\section{B. DETECTING BAD-FAITH CONSTRUCTION}

One way to understand bad-faith constitutional construction is as follows: When a judge takes an oath to follow "this Constitution," the judge forgoes the opportunity to change the Constitution through adjudication. It is bad faith for a party to exercise his or her discretion to improve, evade, or get out of the deal. If judges use their discretion to adopt constitutional constructions that undermine rather than adhere to the spirit of "this Constitution," they are evading the deal they made when they received powers in return for their oath to uphold "this Constitution"- and thus, whatever their motives, they are acting in bad faith.

Lee Strang has cautioned against evaluating whether originalist interpretation has been performed in subjective good faith. ${ }^{178}$ Such inquiries, argues Strang, invite scholars and litigants to "delv[e] into the nonjudicial utterances of judges to try to show subjective bad faith," potentially undermining and even paving the way for the overruling of valuable rules on the basis of (unwarranted) doubt concerning the motivations of those who formulated them. ${ }^{179}$ Further, "intrusive search[es] into judges' nonjudicial writings and statements" could "discourage qualified personnel from accepting judicial office."180

These points are well taken. Yet, whereas determining whether a particular construction is a "good-faith construction" does involve inquiry into the subjective purpose of the judge, that inquiry is limited to a singular and narrow question: Did the judge attempt to recapture the forgone opportunity to change or amend the written Constitution, after having been empowered as a judge on condition of taking an oath of fidelity to "this Constitution"? Further, because the identity of the function or functions of a particular provision is a fact to be discovered rather than invented, whether a judge has acted with subjective bad faith can and should be assessed objectively by examining the function or functions of the text the judge has identified and the evidence put forward by the judge concerning the identity of those functions. There is no need to directly inquire into her mental state.

An objective appraisal of good faith can look like this: Has the judge taken account of the text, structure, and history of the provision? Has she explained why text, structure, and history point towards a particular function? If a provision serves as a number of functions and she has concluded that one is particularly relevant, has she explained why? If more than one is relevant, has she sought to identify which function is of primary importance? Finally: does her construction

178. See Lee J. Strang, An Originalist Theory of Precedent: The Privileged Place of Originalist Precedent, 2010 BYU L. REV. 1729, 1743-50 (2010).

179. Id. at 1744 .

180. Id. 
have the effect of rendering the text a nullity, of little or no practical significance, thereby eliminating it as a constraint on the fiduciary agents of the people?

Evaluating constructions is a more complex matter. It will be difficult to determine whether the articulation of a rule following a good-faith effort to ascertain the letter and a successful identification of the spirit of a provision is itself performed in good faith. Without knowing how a newly-minted rule will apply in future cases, we can only evaluate the arguments that the judge has made to justify the rule and the consequences of the application in a given case.

In assessing whether a judicial construction was in good faith, we may ask the following: Has the judge given a convincing explanation of why the rule is consistent with the spirit of the provision? Has she explained how the rule will produce results consistent with the spirit of the provision, not just in this case, but in future cases? Has she considered and responded to counterarguments? Is it evident how the application of the rule in the instant case produces a result that is consistent with the spirit?

It may be that a rule that is effective at implementing a constitutional guarantee at time $A$ turns out to be ineffective, counterproductive, or unmanageable at time $B .{ }^{181}$ When confronted with arguments that a rule has failed in practice to effectuate the law's spirit, judges must be prepared to reevaluate that rule. At the same time, a decision to preserve a bad rule is not necessarily an act of bad faith. We should ask: Has the judge acknowledged any credible evidence in the record that a rule has proven ineffective, counterproductive, or unmanageable? Has he responded to arguments based on that evidence? Has he applied the rule in the case at hand in a way that inspires confidence in the rule?

Good-faith construction will not always produce one and only one rule. Thus, it will not eliminate the discretion lodged in the fiduciary agents of the people, any more than the duty of good-faith performance of contracts eliminates all discretion enjoyed by contracting parties. That does not trouble us-we do not seek to eliminate discretion. ${ }^{182}$ As compared to alternative approaches that leave all linguistically permissible rules on the table, our approach makes it marginally more likely that judges will arrive at rules that are consistent with the Constitution's spirit. The latter is our primary goal.

Finally, suppose that Strang is correct that overzealous policing of judicial bad faith in the context of constitutional interpretation may discourage qualified personnel from seeking office. That concern could be addressed through working to create a legal-cultural norm pursuant to which we are justified in presuming good faith and the burden on those who would charge bad faith is therefore properly demanding.

181. We hope to explore how judges can deal with this problem in greater depth in a future work.

182. Good-faith construction may not always yield one and only one result- thus, it may not always be determinate - but the set of results that it will produce will not be "identical with the set of all imaginable results"- thus, it will not be indeterminate, but underdeterminate. Solum, supra note 39, at 473. 


\section{Examples of Good-Faith and Bad-Faith Construction}

To show how good-faith construction can work in practice and how we can distinguish between good-faith and bad-faith construction, we now consider two judicially-constructed doctrines.

\section{A. GOOD-FAITH CONSTRUCTION: THE REASONABLE REGULATION OF FIREARMS}

Demonstrating that any particular construction is consistent (or inconsistent) with the letter and the spirit of the Constitution requires a deeper dive into both the original meaning and original function(s) of the relevant text than is feasible in this space. So, to illustrate what we mean by good-faith construction, we turn to the judicial implementation of a constitutional provision, the original public meaning of which has been extensively examined by scholars and authoritatively adjudicated by the Supreme Court after consideration of voluminous evidence: The Second Amendment. We choose Heller, not merely for its current sociopolitical relevance, but because it illustrates the incapacity of originalist interpretation supported by extensive research, standing alone, to resolve certain hard constitutional questions.

Although acknowledging that others will differ, for purposes of this analysis, we take as given what we think the weight of the evidence establishes: ${ }^{183}$ that the Court was correct to hold in District of Columbia v. Heller ${ }^{184}$ that "the right to keep and bear arms" in the Second Amendment refers to a right possessed by individuals; a right that may be exercised outside the context of actual service in an organized militia. We also take as given that this individual right is among the "privileges or immunities of citizens of the United States" that is expressly protected by Section 1 of the Fourteenth Amendment. ${ }^{185}$ How then should courts give legal effect to this right?

We have already touched briefly upon a much-disparaged ${ }^{186}$ passage in Justice Scalia's opinion for the Court in Heller in which he described a number of laws targeting particular weapons and persons as "presumptively lawful." Yet, because he presented little or no historical evidence that the original meaning of the Second Amendment's text was understood to include such exceptions, his assertions had the appearance of what Justice Scalia, in a heated dissent in another case, called "bald, unreasoned disclaimer[s]." 187

We do not believe that the available evidence of original meaning establishes that the laws that Justice Scalia identified as "presumptively lawful" should in

183. See generally Randy E. Barnett, Was the Right to Keep and Bear Arms Conditioned on Service in an Organized Militia?, 83 TeX. L. REv. 237 (2004) (rebutting later arguments that the Second Amendment only protects a militia-conditioned individual right of persons); Randy E. Barnett \& Don B. Kates, Under Fire: The New Consensus on the Second Amendment, 45 EMORY L.J. 1139 (1996) (rebutting earlier arguments that the Second Amendment protects only a collective right of states to preserve their militia).

184. 554 U.S. 570 (2008).

185. See McDonald v. City of Chicago, 561 U.S. 742, 813, 850 (2010) (Thomas, J., concurring).

186. For a thorough demolition, see generally Lund, supra note 10.

187. Lawrence v. Texas, 539 U.S. 558, 604 (2003) (Scalia, J., dissenting). 
fact be treated as such. If not, that determination could only be justified as a construction, not as an interpretation, of the Second Amendment. Wishing the interpretation-construction distinction away does not make it so. What Justice Scalia needed to do-in a future case, not in Heller-was to more carefully identify the spirit of the Second Amendment to see if the exceptions he flagged were consistent with that spirit. So how is this to be done?

One should begin by identifying the function or functions that the text was designed to perform. Many constitutional provisions were designed to perform several different functions, and judges must be sensitive to the context of the case at hand in deciding which function should guide construction. For example, the Second Amendment's prefatory clause indicates a particular function that some have used to narrow the scope of the right to keep and bear arms: "A well regulated Militia, being necessary to the security of a free State ...."188 But to ascertain the content of this function, one must start with the original meaning of these words.

"Militia" here refers to the "general militia," consisting of the body of the people with their own private arms, ${ }^{189}$ which was deemed "necessary to the security of a free State." ${ }^{190}$ At least one of the original purposes of the Second Amendment was to ensure that the newly-created federal government would not eliminate the pre-existing general militia. ${ }^{191}$

Yet, though the preservation of a general militia composed of individual citizens with their own arms be its express purpose, the Amendment does not specify the function or functions to be fulfilled by the general militia or armed population. There is powerful evidence that the general militia was understood as necessary for both collective and personal self-defense. ${ }^{192}$ Thus, the relevant function of the Second Amendment in cases involving modern restrictions on the private ownership of weapons is that of ensuring that law-abiding citizens can defend themselves against public or private violence-from tyrannical government or from

188. U.S. CONST. amend. II.

189. In the eighteenth century, the term "militia" referred to what was called the "general" militia consisting of "the body of" or "the whole of" the people. See, e.g., VA. DeClaration of Rights of $1776 \S 13$ (1776) (“[A] well-regulated militia, composed of the body of the people . ..."); 3 ELLIOT'S DEBATES, supra note 78, at 425 (remarks of George Mason at Virginia ratifying convention: "Who are the militia? They consist now of the whole people."); Letters from the Federal Farmer (Jan. 25, 1788), in 2 The COMPLETE ANTI-FEDERALIST, supra note 88, at 341 ("A militia, when properly formed, are in fact the people themselves . . . and include . . . all men capable of bearing arms . . .."). It did not refer to organized military units, which were either "select" militia or a standing army, but encompassed all of those who qualified for military service. See Joyce LeE Malcolm, To KeEP And BeAr Arms: The ORIGINS OF AN ANGLO-AMERICAN RIGHT 163 (1994) ("The argument that today's National Guardsmen, members of a select militia, would constitute the only persons entitled to keep and bear arms has no historical foundation.").

190. U.S. Const. amend. II.

191. This was common ground between the Heller majority and Justice Stevens in dissent, both of whom cited copious historical materials in support. Compare District of Columbia v. Heller, 554 U.S. 570, 596-600 (majority opinion) with id. at 641-44 (Stevens, J., dissenting).

192. See id. at 579-92; see, e.g., PA. CONST. art XIII (1776) ("That the people have a right to bear arms for the defence of themselves and the state...." (emphasis added)). 
ordinary criminals. ${ }^{193}$ It is that historically identifiable function that judges should apply in determining how the right to bear arms might "reasonably" be regulated.

Thus, for example, a ban on those "arms" that create an unreasonable risk of harm to innocent third parties even when properly used in self-defense may well be consistent with the original spirit of the Second Amendment, given the great variety of available arms that do not create such a risk. Under this implementing doctrine, if fully automatic "machine guns" that can "spray" bullets by holding down the trigger create an unreasonable risk of harm to innocent third parties when properly used in self-defense, then such weapons may constitutionally be banned.

In recent years, lower courts have developed implementing doctrines which distinguish reasonable from unreasonable regulations of firearms. ${ }^{194}$ One example is Ezell v. City of Chicago, in which a panel of the Court of Appeals for the Seventh Circuit evaluated a city ordinance that required citizens to acquire gun range proficiency before they could own firearms - while at the same time banning all gun ranges from within the city limits. ${ }^{195}$

In her opinion evaluating the gun range ban, Judge Diane Sykes distinguished the "interpretive" issue of whether the Second Amendment protected an individual or a collective right — which she took as settled by Heller-from the "doctrinal" question of how to implement the right. ${ }^{196}$ A second interpretive question involved identifying the original "scope" of the right: "Is the restricted activity protected by the Second Amendment in the first place? The answer requires a textual and historical inquiry into original meaning."197 This, she explained, is analogous to First Amendment inquiries into whether particular types of speech are-like fraud or obscenity-outside the scope of the Amendment. ${ }^{198}$

If "the government cannot establish this - if the historical evidence is inconclusive or suggests that the regulated activity is not categorically unprotected," then there must be a further "inquiry into the strength of the government's justification for restricting or regulating the exercise of Second Amendment rights." 199 In

193. See Nelson Lund, The Second Amendment, Political Liberty, and the Right to Self-Preservation, 39 ALA. L. REV. 103, 117 (1987) (observing that political oppression is not "the main reason modern civilians want to possess arms nor the main effect that private possession of arms has on the political community" and proceeding to consider whether the underlying right to self-defense encompasses also "the people's right to the means of defending themselves from [private violence]").

194. See, e.g., Peruta v. County of San Diego, 824 F.3d 919 (9th Cir. 2016) (en banc) (carry outside the home); Teixeira v. County of Alameda, 822 F.3d 1047 (9th Cir. 2016) (gun stores); Friedman v. City of Highland Park, 784 F.3d 406 (7th Cir. 2015) (assault weapons); Jackson v. City of San Francisco, 746 F.3d 953 (9th Cir. 2014) (safe storage laws).

195. 651 F.3d 684, 691 (7th Cir. 2011).

196. Id. at 700 .

197. Id. at 701 (citing Eugene Volokh, Implementing the Right to Keep and Bear Arms for SelfDefense: An Analytical Framework and a Research Agenda, 56 UCLA L. REV. 1443, 1449 (2009)).

198. See id. at 702 .

199. Id. at 703 . 
short, there must be "heightened" scrutiny, not the "any conceivable rationale" approach of "rational basis" scrutiny. ${ }^{200}$

Sykes opted for a First Amendment-style approach consisting of two steps. First, "a severe burden on the core Second Amendment right of armed selfdefense will require an extremely strong public-interest justification and a close fit between the government's means and its end." ${ }^{201}$ Second, laws that restrict activity "lying closer to the margins of the Second Amendment right, laws that merely regulate rather than restrict, and modest burdens on the right may be more easily justified. How much more easily depends on the relative severity of the burden and its proximity to the core of the right." ${ }^{202}$ Sykes then concluded that because the government's "claimed public-safety concerns" were supported by "no data or expert opinion," they failed the articulated test and were thus unconstitutional. ${ }^{203}$

Legislators, too, have a fiduciary duty to the people to exercise their discretionary powers in good faith. As Justice Bradley put it when discussing states' reserved police powers, "there are certain fundamental rights which this right of regulation cannot infringe. It may prescribe the manner of their exercise, but it cannot subvert the rights themselves." ${ }^{204}$ Sykes's implementing doctrine is calculated to identify when the legislature is opportunistically seeking to subvert the right to keep and bear arms rather than merely regulating the manner of its exercise. Hers is a good-faith constitutional construction.

But judges may also seek to subvert a right under the rubric of construction. We now turn to an example of such bad-faith construction.

\section{B. BAD-FAITH CONSTRUCTION: THE SUBSTANTIAL-EFFECTS DOCTRINE}

In a series of cases, the New Deal Supreme Court held that Congress could regulate wholly intrastate activity that, when combined or "aggregated" with other like activity, has a "substantial effect" on interstate commerce. In the 1937 case of NLRB v. Jones \& Laughlin Steel Corp., the Court began this doctrinal innovation by allowing Congress to empower the National Labor Relations Board "to prevent any person from engaging in any unfair labor practice . . a affecting commerce." 205

The problem was not with the statute's definition of "commerce," which was faithful to both original public meaning and precedent. ${ }^{206}$ The problem was with

200. Id. at 701 ("If all that was required to overcome the right to keep and bear arms was a rational basis, the Second Amendment would be redundant with the separate constitutional prohibitions on irrational laws, and would have no effect." (quoting District of Columbia v. Heller, 554 U.S. 570, 628 n.27 (2008))).

201. Ezell, 651 F.3d at 708 .

202. Id.

203. Id. at 709 .

204. Slaughter-House Cases, 83 U.S. (1 Wall) 36, 114 (1873) (Bradley, J. dissenting).

205. 301 U.S. 1, 30 (1937).

206. See id. at 31 (quoting National Labor Relations Act § 2(6), 29 U.S.C. § 152(6) (1935)) (“The term 'commerce' means trade, traffic, commerce, transportation, or communication among the several States, or between the District of Columbia or any Territory of the United States and any State or other 
the function of the doctrine that the Court devised to enable Congress to reach wholly intrastate activity because of its "effect" on interstate commerce. Had this doctrine been confined to actions that literally burden or obstruct interstate commerce itself, it would have been within the realm of good-faith construction. ${ }^{207}$ But it was soon extended well beyond.

Four years later, the Court in United States $v$. Darby extended the power of Congress to regulate manufacturing by prohibiting "the employment of workmen in the production of goods 'for interstate commerce' at other than prescribed wages and hours."208 Once again, the problem was not with the Court's interpretation of the text of the Commerce Clause. The Court acknowledged that the term "commerce" did not include the activity of manufacturing: "While manufacture is not of itself interstate commerce, the shipment of manufactured goods interstate is such commerce and the prohibition of such shipment by Congress is indubitably a regulation of the commerce."209

The Court then made clear that the substantial-effects doctrine was in fact based on an expansive reading of the Necessary and Proper Clause: ${ }^{210}$

The power of Congress over interstate commerce is not confined to the regulation of commerce among the states. It extends to those activities intrastate which so affect interstate commerce or the exercise of the power of Congress over it as to make regulation of them appropriate means to the attainment of a legitimate end, the exercise of the granted power of Congress to regulate interstate commerce. ${ }^{211}$

The citation to the Necessary and Proper Clause case of $M c C$ ulloch for this proposition, rather than the Commerce Clause case of Gibbons v. Ogden, ${ }^{212}$ was a tell. ${ }^{213}$

Territory, or between any foreign country and any State, Territory, or the District of Columbia, or within the District of Columbia or any Territory, or between points in the same State but through any other State or any Territory or the District of Columbia or any foreign country.").

207. Indeed, in contrast with Darby and Wickard, the New Deal Justices thought their decision on Jones \& Laughlin Steel was consistent with existing Commerce Clause doctrine. See Barry Cushman, Inside the "Constitutional Revolution" of 1937, 2016 S. CT. REv. 367, 406 (2017) ("[M]any contemporary observers saw the opinions in [the Labor Board Cases] as fully consistent with prevailing doctrine."); $i d$. at 408 ("[W]hen Congress asserted genuinely novel claims of regulatory authority over manufacturing and agriculture ... several of the Justices did not regard the Labor Board decisions as providing adequate constitutional foundation for those measures.").

208. 312 U.S. 100,108 (1941).

209. Id. at 113 .

210. U.S. CONST. art. I, § 8, cl. 18.

211. Darby, 312 U.S. at 118-19 (citing McCulloch v. Maryland, 17 U.S. (4 Wheat.) 316, 421 (1819)).

212. 22 U.S. (9 Wheat.) 1 (1824).

213. See Stephen Gardbaum, Rethinking Constitutional Federalism, 74 Tex. L. Rev. 795, 807-08 (1996) (observing that "the New Deal Court's own constitutional justification for its radical expansion of the scope of federal power over commerce was that the congressional measures in question were valid exercises of the power granted by the Necessary and Proper Clause" and that "the Court did not simply and directly enlarge the scope of the Commerce Clause itself, as is often believed"). 
In a crucial move, the Court also rejected any consideration of whether the motive or purpose of the prohibition was to regulate wholly intrastate noncommercial activity: "The motive and purpose of a regulation of interstate commerce are matters for the legislative judgment upon the exercise of which the Constitution places no restriction and over which the courts are given no control.",214

Thus, although citing $M c C$ ulloch in support of its expansive reading of the Necessary and Proper Clause, the Court repudiated sub silentio Chief Justice John Marshall's limiting principle in that case:

[S]hould congress [sic], under the pretext of executing its powers, pass laws for the accomplishment of objects not intrusted to the government; it would become the painful duty of this tribunal, should a case requiring such a decision come before it, to say that such an act was not the law of the land. ${ }^{215}$

Simply put, the Court in Darby denied that it had the authority to make an inquiry into the possibility of pretext that Marshall insisted that the Court was duty-bound to make.

The next important step in this doctrinal development came in Wickard $v$. Filburn. ${ }^{216}$ In Wickard, the Court reaffirmed the doctrine of Darby that Congress may reach activity, "even if [the] activity be local and though it may not be regarded as commerce," 217 thereby preserving the original meaning of the Commerce Clause. By using the substantial effects construction of Darby, the Court in Wickard was able to reach the conclusion that such local and noncommercial activity "may still, whatever its nature, be reached by Congress if it exerts a substantial economic effect on interstate commerce." 218

But the Court in Wickard then extended Darby's substantial-effects doctrine still farther. The Court added what has come to be called the "aggregation principle." According to this constitutional construction, even if the effect of a particular person's activity has on interstate commerce is "trivial by itself," Congress may still reach it if "his contribution, taken together with that of many others similarly situated, is far from trivial." 219

The substantial-effects doctrine-as supplemented by the aggregation principle - is a construction ostensibly employed to implement the (textual) power of Congress to regulate "commerce ... among the states," ${ }^{, 20}$ together with the incidental powers affirmed in the Necessary and Proper Clause. But it is profoundly unfaithful to the structure in which both clauses appear-the scheme of enumerated Congressional powers established by Article I, Section 8. The original

\footnotetext{
214. Darby, 312 U.S. at 115.

215. McCulloch, 17 U.S. at 423 (emphases added).

216. 317 U.S. 111 (1942).

217. Id. at 125 (emphasis added).

218. Id.

219. Id. at 127-28 (emphasis added).

220. U.S. CONST. art I, § 8, cl. 3.
} 
function of this structural design element was to specifically identify those legislative powers "to which the separate States are incompetent, or in which the harmony of the United States may be interrupted by the exercise of individual Legislation," 221 rather than rely on any general and vague grant of legislative power that would be insufficient to prevent a consolidated national government.

That this was the original function of the enumerated powers scheme was acknowledged by the New Deal Court Justices themselves when they declared in Jones \& Laughlin Steel that:

\begin{abstract}
Undoubtedly the scope of this power must be considered in the light of our dual system of government and may not be extended so as to embrace effects upon interstate commerce so indirect and remote that to embrace them, in view of our complex society, would effectually obliterate the distinction between what is national and what is local and create a completely centralized government. ${ }^{222}$
\end{abstract}

And yet this is exactly what the substantial-effects doctrine as expanded in Darby and Wickard accomplished: the obliteration of the distinction between what is national and what is local, potentially empowering a completely centralized government.

That Darby and Wickard represented a departure from the doctrines to which the Court continued to adhere in Jones \& Laughlin Steel is evidenced by the fact that "Darby (1941) cited the Labor Board Cases only once in passing; Wickard $v$. Filburn (1942) did not cite them at all. The Justices of the early 1940s treated the Labor Board Cases not as a germinal manifesto on the scope of federal power, but instead as yesterday's news." 223 Indeed, the Court found this further extension of congressional power so problematic, it held the case over for reargument from one term to the next. ${ }^{224}$

To reach the conclusion that the New Deal Court was engaging in bad-faith construction, we need not directly inquire into the subjective motives of the Justices. As it happens, however, we now have access to the thoughts of the justice who wrote the opinion in Wickard.

As presented by Barry Cushman, Justice Robert Jackson was fully aware that the doctrine the Court adopted in Wickard would fundamentally depart from precedent and leave the text of the Constitution enumerating the powers of Congress unenforced by the courts. In a memo to his law clerk in the summer of

221. 1 The Records of the Federal Convention of 1787, at 21 (Max Farrand ed., 1937). As explained by Joseph Lynch, this wording of the Virginia plan was replaced by the enumeration of Congressional powers after the great compromise in which the states would have equal representation in the Senate. See Joseph M. Lynch, Negotiating the Constitution: The Earliest Debates over ORIGINAL INTENT 21 (1999).

222. NLRB v. Jones \& Laughlin Steel Corp., 301 U.S. 1, 37 (1937).

223. Cushman, supra note 207, at 408 (footnotes omitted).

224. Id. ("[E]ven a Court now dominated by Roosevelt appointees required reargument and a good deal of soul searching before a majority could be assembled to uphold federal regulation of the growth of wheat for home consumption on Roscoe Filburn's farm."). 
1942, Jackson wrote: "If we sustain the present Act, I don't see how we can ever sustain states' rights again as against a Congressional exercise of the commerce power." 25 And "[i]f we sustain the present case, the judicial shibboleths as to limitation of the commerce power are without practical meaning, and that is within the commerce power which Congress desires to regulate." ${ }^{226}$ In another memo Jackson wrote:

It is perhaps time that we recognize that the introduction of economic determinism into constitutional law of interstate commerce marked the end of judicial control of the scope of federal activity. . . . A frank holding that the interstate commerce power has no limits except those which Congress sees fit to observe might serve a wholesome purpose. In order to be unconstitutional by the judicial process if this Act is sustained, the relation between interstate commerce and the regulated activity would have to be so absurd that it would be laughed out of Congress. ${ }^{227}$

But the Justices in Wickard decided against a "frank holding." Indeed, with rare exceptions, ${ }^{228}$ the New Deal Court's expansion of federal power was accomplished not by expressly abandoning the original meaning of the letter of the Constitution, but by adopting constitutional constructions that undercut its spirit. The function of enumerating powers was to keep Congress within textually specified bounds - thereby preserving our federal system — not to empower Congress to regulate anything it "sees fit to observe might serve a wholesome purpose."229 Because the aggregation principle effectively did the latter, it must be understood as a bad-faith construction.

\section{Objections To Good-Faith Construction}

Good-faith construction meets a well-recognized need to guide judges in discharging their duty when the original meaning of the text runs out-and to provide members of the public with assurance that they will not be exposed to arbitrary judicial power. That is to say, it aspires to do for constitutional construction what Burton's "forgone opportunities" theory did for the duty of good-faith performance in contract law, and what original meaning originalism did for constitutional interpretation. We now turn to some potential objections to our theory.

\section{A. DOES IT REVIVE THE OLD ORIGINALISM?}

Viewing proper construction as a product of, and limited to, the original spirit of the Constitution strikes some of the same chords as appeals to the original

225. Barry Cushman, Rethinking the New Deal Court: The Structure of a Constitutional REVOLUTION 216-18 (1998).

226. Id. at 218 .

227. $I d$.

228. See, e.g., United States v. Se. Underwriters Ass'n, 322 U.S. 533, 553 (1944) (holding that the power to regulate commerce includes the power to regulate insurance).

229. CuSHMAN, supra note 225 , at 218. 
intentions of the Framers - that is, it echoes proto-originalism. ${ }^{230}$ The appeal of proto-originalists' invocation of "original intent" has always been that it purports to put the "Framers' values" ahead of the judge's own, and thereby constrains the judge's discretion. This is just what we are advocating: putting the objectively identified original functions of the text itself ahead of extralegal preferences.

But we are not advocating a return to proto-originalism. When seeking to apply the text to modern circumstances, proto-originalists often went beyond identifying the original function of a provision to ask, "What would the Framers do?" One of us has disparaged this as "channeling" the Framers. ${ }^{231}$ Unlike inquiring into the communicative content of constitutional text at the point of ratification, asking how the Framers would have applied the text to facts inconceivable to them-think violent video games ${ }^{232}$ - is a counter-factual thought experiment. We do not recommend it.

We also do not recommend relying entirely upon how the Framers thought the text applied, or would apply, to particular factual circumstances, which has been called "original expected application." 233 Had they actually conceived of a particular application, they may well have been in error. For example, we believe that eight Justices were wrong in how they applied the Privileges or Immunities Clause to sex discrimination in Bradwell v. Illinois, irrespective of whether the Framers of the Fourteenth Amendment believed that excluding women from the practice of law was reasonable. ${ }^{234}$

In contrast, good-faith construction seeks to identify empirical facts: the original functions of the Constitution's provisions and structural design elements. The Constitution was the result of a careful-if often contentious-design process. Each constitutional provision and structural design element was crafted for a reason or multiple reasons. We can discover these reasons by examining how the Constitution's various components interact with one another, and by consulting what was said about them both in public and in private.

To appreciate why it is appropriate to consult private as well as publicly available evidence, consider an old-fashioned analogue watch. A watch has a primary function - to tell time - that is discoverable by examining it and figuring out what the numbers around the circumference and the hands that point to them

230. Not to be confused with the intentionalism of Alexander, Kay, or Prakash, which is resolutely empirical.

231. See Randy E. Barnett, The Relevance of the Framers' Intent, 19 HARV. J.L. \& PuB. POL'y 403, 405 (1996) ("One may think of this as a type of constitutional 'channeling' in which originalist clairvoyants ask: 'Oh Framers, tell us what would you think about the following law?'”). For a call for originalists to return to this approach, see Steven D. Smith, Meanings or Decisions? Getting Originalism Back on Track, LAw \& LIBERTY (Dec. 2, 2014), http://www.libertylawsite.org/liberty-forum/meaningsor-decisions-getting-originalism-back-on-track/ [https://perma.cc/Q4U2-L7PE] (describing "original decisions" originalism).

232. See generally Brown v. Entm’t Merchs. Ass'n, 564 U.S. 786 (2011) (deciding “whether a California law imposing restrictions on violent video games comports with the First Amendment").

233. Balkin, supra note 27 , at 293.

234. Bradwell v. Illinois, 83 U.S. (16 Wall.) 130, 142 (1872); see BARNETT, supra note 112, at 8789, 117-21 (explaining why Bradwell was wrongly decided). 
represent. Now open the watch and see the flywheel, gears, and springs, each of which has its own secondary function that facilitates the fulfillment of the watch's primary function. Unless one is a watchmaker, the exact function of each part is difficult to discern. And these intended functions of the constituent parts of the watch are different than the motives of the watch designer, which may have been to earn a paycheck, or even the esteem of fellow watch designers.

One way to identify these functions would be to speak with the watch designer. Failing that, one could consult the written comments by the designer about what each part is supposed to do and why it was designed in a particular way rather than in another way. The watch designer's views are authoritative, not because he has some legal power over a watch user, but because of what he knows about watch design in general and the choices he made when designing this particular watch.

As one of us has observed, the Framers of the Constitution can be viewed as "designers or architects of the lawmaking 'machine."”235 Accordingly,

[w] consult them when we want to know how the machine is supposed to work, not because they are a surrogate for the majority of the people who lived two hundred years ago, but because they might have special insight into the machine that they designed-especially its internal quality-control procedures. They gave its purpose and design much thought-perhaps more thought than we have - and we benefit from their learning in interpreting their design. ${ }^{236}$

Their beliefs about the functional construction of the Constitution play an evidentiary role.

This way of conceptualizing Framers' intent has two advantages. First, the "Framers-as-Designers" approach "explains why we remain so fascinated and influenced by the views of the small group of persons who framed - as opposed to ratified - the Constitution . . .."237 Indeed, "we generally confine our attention to just a handful of the Framers, such as James Madison or James Wilson" or Gouverneur Morris, who had the most direct role in actually drafting the text of the Constitution, "as opposed to the views of other members of the convention or of the reigning majority of the time." ${ }^{\prime 238}$ We pay careful attention to these Framers in particular because we believe that they had unique insight into the functioning of the system they helped design. With regard to the Fourteenth Amendment, scholars have rightly focused attention on John Bingham, its principal drafter. ${ }^{239}$

235. See Barnett, supra note 231, at 403, 408 (distinguishing "two reasons to consult the Framers. The first views the Framers as wardens; the second as designers or architects").

236. $I d$.

237. Id. at 408-09.

238. Id. at 409.

239. See, e.g., Gerard N. Magliocca, American Founding Son: John Bingham and the InVENTION OF THE FourteEnth AMENDMENT (2013); Richard L. Aynes, On Misreading John Bingham and the Fourteenth Amendment, 103 Yale L.J. 57 (1993); Michael Kent Curtis, John A. Bingham and 
Second, "according to the Framers-as-Designers approach, we consult the writings of the Framers to discern not their specific hypothetical intentions towards particular legislation, but the [design] principles" that explain the specific provisions and general structure of the Constitution. ${ }^{240}$ "Among these [design] principles are federalism, separation of powers," and the duty to apply the Constitution as supreme law. ${ }^{241}$

The Constitution can be thought of as describing a device or mechanism like a watch. Like a watch, the Constitution as a whole has functions (described in the Preamble). Like the flywheel, gears, and springs of a watch, each of its clauses was designed to work harmoniously with the others to fulfill those functions. Like a watch, each of its constituent parts have their own secondary functions as means to the more general ends. ${ }^{242}$

Like a watch, the Constitution was the product of deliberate human design rather than uncoordinated human action. ${ }^{243}$ Where the functions or purposes of a provision are not obvious, we can attempt to reverse engineer the design from close examination of its workings. But we can also seek out the explanations left behind by its designers. Even if these explanations were not published, they would still help us to understand the functions of each constituent part.

\section{B. BUT WHAT ABOUT THE SUMMING PROBLEM?}

But wait! Didn't Paul Brest and others demonstrate the impossibility of identifying the collective intentions of myriad Framers and Ratifiers? ${ }^{244}$ Didn't we see in Part II that this is why originalists moved to original meaning in the first place? Don't all these same problems now return with originalist construction based on the "purposes" of the Constitution?

Well, not so fast. Even Brest acknowledged that the "general purposes" of constitutional provisions are ascertainable and that it is "a perfectly sensible strategy of constitutional decisionmaking" to seek to adhere to them. ${ }^{245}$ Judges, he

the Story of American Liberty: The Lost Cause Meets the "Lost Clause", 36 AKron L. REV. 617, 65561 (2003); Kurt T. Lash, The Origins of the Privileges or Immunities Clause, Part II: John Bingham and the Second Draft of the Fourteenth Amendment, 99 GEO. L.J. 329, 340 (2011) (tracing Bingham's drafting efforts and using his public statements about the text to inform interpretation of the Fourteenth Amendment).

240. Barnett, supra note 231 , at 409.

241. Id.

242. John Manning has drawn a similar distinction between the "ulterior" or "background" purposes of a statute and the "implemental" purposes that particular provisions are designed to achieve. See John F. Manning, The New Purposivism, 2011 SuP. CT. REv. 113, 115 (“[T] he law's 'purpose,' properly understood, embodies not merely a statute's substantive ends (its 'ulterior purposes'), but also Congress's specific choices about the means to carry those ends into effect (its 'implemental purposes').").

243. With apologies to Friedrich Hayek. See F.A. HayeK, The FAtal Conceit: The Errors of Socialism 6 (W.W. Bartley, III ed., 1988) ("To understand our civilisation, one must appreciate that the extended order resulted not from human design or intention but spontaneously . . .."). We note, however, that Hayek described government as a "deliberate contrivance." 1 F.A. HAYEK, LAW, LEGISLATION AND LIBERTY: RULES AND ORDER 124 (1973).

244. See supra Section II.A.

245. Brest, supra note 19, at 231. 
observed, "are more concerned with the adopters' general purposes than with their intentions in a very precise sense." ${ }^{246}$ Describing what he called "moderate intentionalism," he wrote, "A moderate intentionalist applies a provision consistent with the adopters' intent at a relatively high level of generality, consistent with what is sometimes called the "purpose of the provision." 247 The moderate intentionalist "attempts to understand what the adopters' purposes might plausibly have been, an aim far more readily achieved than a precise understanding of the adopters' intentions." 248

Together, two recent developments in philosophy suggest that the pursuit of, and adherence to, the adopters' purposes, is indeed possible. The first is artifact theory, which defines an artifact as "an object that has been intentionally made or produced for a certain purpose." ${ }^{249}$ As explained by Risto Hilpinen, an artifact requires a maker or designer, ${ }^{250}$ but the concept "allows the possibility that an artifact has several authors who contribute to its production. Such objects may be termed 'collectively produced artifacts.",251

Of particular relevance to our discussion of "Framers' intent" is that artifacts have functions or purposes that are imparted to them by their makers or authors, which Hilpinen labels productive intentions. ${ }^{252}$ The very existence of the artifact, as well as its properties, "depend[s] on an author's intention to make an object of certain kind." ${ }^{253}$ The author's actions to produce the object provides the "causal tie between an artifact . . . and its author's productive intention." ${ }^{254}$ Hilpinen details how we can discover the productive intention behind an artifact:

An author's productive intention is often expressed by cognitive artifacts which show the character of the intended artifact and the way it should be

246. Id. at 205 (emphasis added).

247. Id. at 223 (emphasis added).

248. Id. (emphasis added).

249. Risto Hilpinen, Artifact, in The Stanford Encyclopedia of Philosophy (Edward N. Zalta ed., Winter 2011 ed.), https://plato.stanford.edu/archives/win2011/entries/artifact/ [https://perma.cc/ M6KW-4ZTZ]. While this Article was in production, Hilpinen's Encyclopedia entry was replaced by a new one. See Beth Preston, Artifact, in The Stanford EnCyClopedia OF Philosophy (Edward N. Zalta ed., forthcoming 2018), https://plato.stanford.edu/archives/fall2018/entries/artifact/ [https://perma.cc/ 3XPC-YNMK] (last updated July 18, 2018). However, the Encyclopedia notes: "The latest version of the entry 'Artifact' (new, rewritten entry) is not yet archived and may change before it is archived in the Fall 2018 edition. You should, if possible, wait for the Fall 2018 archived edition of the Encyclopedia to cite this version." Author and Citation Information for "Artifact," in THE STANFORD ENCYCLOPEDIA OF PHILOSOPHY, https://plato.stanford.edu/cgi-bin/encyclopedia/archinfo.cgi?entry=artifact [https://perma. cc/X79R-SU45] (last visited Aug. 23, 2018). We continue to quote from Hilpinen's explanation of artifacts as it bears more closely on our own analysis.

250. Hilpenen, supra note 249 ("An artifact has necessarily a maker or an author; thus artifact and author can be regarded as correlative concepts.").

251. Id.

252. See id. ("When a person intends to make an object of a certain kind, his productive intention has as its content some description of the intended object, and the author's intention 'ties' to an artifact a number of predicates which determine the intended character of the object.").

253. $I d$.

254. Id. 
constructed, for example, a drawing, a diagram, or a model of the artifact, together with a list of parts and materials and a set of instructions (a precept) for the production process. ${ }^{255}$

Hilpinen emphasizes that "[s]uch representations are especially important in the case of collectively produced complex artifacts" because they are "necessary for successful communication among the authors of the artifact and for the coordination of their productive actions." 256

Finally, Hilpinen explains that "[t]he study of artifacts (qua artifacts) is intrinsically evaluative, since viewing an object as an artifact means viewing it in the light of intentions and purposes." ${ }^{257}$ By this, Hilpinen means we evaluate whether the artifact well serves or ill serves its intended purposes. Nevertheless, the purposes the artifact was intended to serve can be discovered through empirical inquiry.

Another example illustrates how artifact theory helps explain group intentions. Consider a smart phone, which is both far more complex than a watch and is designed by teams, with different groups working on hardware and software. Smart phones are designed to make telephone calls, to send and receive emails and text messages, to function as a camera, and to run apps that enable the phone to perform many other functions. Regardless of how many people contributed to its design, we have no difficulty discerning the functions that a smart phone was "intended" to perform. The summing problem simply drops away because identification of the functions as a property of the artifact is conceptually distinct from an inquiry into the psychological motives and purposes of the individual members of the various design teams.

From one perspective, the Constitution can itself be treated as an artifact that was made or created by a collective body of authors who had a productive intention to design an institution that functioned in certain ways to accomplish certain ends. From another perspective, the Constitution is the "set of instructions" or a recipe ${ }^{258}$ made by the authors to describe how the created complex artifact-a new national government-is supposed to operate.

From either perspective, originalism is a commitment to following this original design, first, by correctly interpreting the instructions- the meaning of which was fixed at the time they were ratified into law-and, second, by implementing the instructions in a manner that faithfully effectuates their original functions. By this route, we arrive at a unified theory of originalism.

The possibility of pursuing agreed-upon original functions also draws support from Christian List and Philip Pettit's work on group agency. ${ }^{259}$ List and Pettit's

255. $I d$.

256. $I d$.

257. $I d$.

258. See Lawson, On Reading Recipes, supra note 37, at 1826.

259. See Christian List \& Philip Pettit, Group Agency: The Possibility, Design, and Status of Corporate Agents (2011). See generally Abraham Sesshu Roth, Shared Agency, THE STANFORD ENCYCLOPEDIA OF PHILOSOPHY: SUMMER 2017 EDITION, https://plato.stanford.edu/archives/sum2017/ 
project is not only to identify the existence and character of group agents and their intentions, but to show how such agents can be held morally responsible for "their" actions. Along the way, they ask, "How could a multi-member group move from the distinct and possibly conflicting intentional attitudes of its members to a single system of such attitudes endorsed by the group as a whole?"260 In other words, "how can a group of individuals make collective judgments on some propositions based on the group members' individual judgments on them?"261

Because their analysis of these questions is too rich to be fully reported here, the general conclusion that List and Pettit reach will need to suffice:

A group forms a judgment or other attitude over a certain proposition when the proposition is presented for consideration-it is included in the agenda - and the group takes whatever steps are prescribed in its organizational structure for endorsing it. . . [T] [Tese steps may involve a vote in the committee-of-thewhole, a vote in an authorized subgroup, or the determination of an appointed official. ${ }^{262}$

To simplify, individual agents are individually responsible for their choice to design and make a group that has the structural or procedural features necessary to reach decisions about its ends and to adopt means by which those ends can be achieved. Not just any collection of persons, but a group that is organized in this way, the authors contend, has all the requirements of a responsible agent.

By integrating the concept of an artifact that is made for a purpose with a coherent account of group agency, we can identify a potential solution to the summing problem. Those who gathered in Philadelphia can be said to have organized themselves so as to constitute a group agent. The intentions of the Convention, the group agent, can be understood as the functions of the artifact they designed, the Constitution, as a whole and of its constituent parts (rather than the personal motives of each individual designer).

We do not affirm the correctness of the above renditions of artifact or group agency theory. We have not done the work necessary to make an independent judgment about the soundness of either philosophical stance. But both the common sense of lawyers and contemporary philosophy support our contention that, when the intentions at issue are the functions of the various clauses of the Constitution, the summing problem isn't all that problematic.

\footnotetext{
entries/shared-agency $/$ [https://perma.cc/8SHN-HURA]. For theories of statutory interpretation that draw upon List and Pettit's work, see generally RichARD EKINS, THE NATURE OF LEGISLATIVE INTENT (Timothy Endicott et al. eds., 2012); Victoria Nourse, MisREading LaW, MisReading DemOcracy (2016).

260. LIST \& PETTIT, supra note 259, at 42 .

261. Id. at 43 .

262. Id. at 159 .
} 


\section{WHY DISTINGUISH INTERPRETATION FROM CONSTRUCTION?}

If the Constitution's letter and spirit can both be ascertained empirically by investigating similar evidence, why persist in distinguishing between interpretation and construction? First, because identifying the communicative content of a text is still a different activity than identifying its intended function. Determining that the Second Amendment was designed to protect an individual right to possess and carry weapons does not tell us whether a machine gun is a protected "[a]rm[]." Second, because the respective activities have a lexical order, the spirit should not be used to override the letter. When the letter is clear, it controls.

Consider that some nonoriginalists who favor a "living constitution" profess to be faithful to the Constitution's text but operate by identifying the purpose or underlying principles of the text, and then leaving the text behind or limiting its scope. By this reasoning, if the original purpose of enumerating Congressional powers was to equip Congress to remedy truly "national" problems that are beyond the competence of states to address, and we now believe we know of national problems that cannot be addressed through those powers, the Constitution can be construed to give Congress additional powers to address them.

We reject this move as illegitimate - as constitutional amendment by way of Article III rather than Article V. Keeping the interpretation-construction distinction in view and prioritizing the letter in cases of perceived conflict is necessary to prevent the spirit from being used, under the rubric of construction, to undermine or supplant what interpretation yields about the meaning of the letter.

\section{WILL THE SPIRIT LEAD JUDGES ASTRAY?}

Judicial recourse to the spirit of the law has a bad reputation among some textualist originalists, who offer two related objections to inquiry into the spirit of the text. First, these originalists say that the spirit of the law is simply not the law and thus not a proper object of judicial inquiry. ${ }^{263}$ Second, they claim that recourse to the spirit will lead judges to depart from the law's communicative content. $^{264}$

Textualist originalists might cite Hamilton's response to Anti-Federalists concerns that federal judges would draw upon the spirit of the Constitution to enlarge federal power. ${ }^{265}$ In Federalist 81 , Hamilton replied that "there is not a syllable in

263. See Frank H. Easterbrook, What Does Legislative History Tell Us?, 66 CHI.-KENT L. REV. 441, 443 (1990) (arguing that "laws themselves do not have purposes or spirits-only the authors are sentient"). As we saw, supra Section V.B., artifact and group agency theory undermine Judge Easterbrook's claim.

264. See John F. Manning, Textualism and Legislative Intent, 91 VA. L. REV. 419, 450 (2005) (concluding that, in the context of statutory interpretation, "efforts to augment or vary the text in the name of serving a genuine but unexpressed legislative intent risks displacing whatever bargain was actually reached").

265. See Brutus, Essay No. XII, (N.Y. J. Feb. 7, 1788), reprinted in 2 The Complete AnTIFEDERALIST, supra note 88, at 423 (warning that judges will draw upon the spirit of the Constitution to "give [the Constitution] such a construction as to extend the powers of the general government, as much 
the plan, which directly empowers the national courts to construe the laws according to the spirit of the constitution." 266

Yet the evidence is overwhelming that recourse to the spirit was a legitimate move in the context of construction during the Founding era. ${ }^{267}$ Nor should Hamilton's statement be understood as rejecting it. After denying that the text of the Constitution empowers courts to "construe the laws according to the spirit of the constitution," Hamilton added "or which gives them any greater latitude in this respect, than may be claimed by the courts of every state." 268 Yet, state courts could-and did-have recourse to the spirit. ${ }^{269}$

Further, Hamilton went on to "admit . . . that the constitution ought to be the standard of construction for the laws, and that wherever there is an evident opposition, the laws ought to give place to the constitution," thus acknowledging that the Constitution authorizes judges to hold unconstitutional laws void. ${ }^{270}$ But, he wrote, "this doctrine is not deducible from any circumstance peculiar to the plan of the convention; but from the general theory of a limited constitution." ${ }^{271}$ Here Hamilton himself is relying on what we are calling the spirit of the text.

Moreover, in Federalist 32, Hamilton accused Anti-Federalists of distorting the spirit of the proposed Constitution in their arguments that it conferred upon Congress an exclusive power to tax all articles other than imports and exports. ${ }^{272}$ Hamilton pointed out that states were specifically forbidden from taxing exports and imports (absent "the consent of the Congress" or "for the purpose of executing [their] inspection laws") "implies an admission that, if it were not inserted, the states would possess the power it excludes; and . . . a further admission, that as to all other taxes, the authority of the states remains undiminished."273 Therefore, Hamilton contended that it "could not have been the intention" to create an exclusive taxing power in Congress, "and that [the Constitution] will not bear a construction of the kind." ${ }^{274}$ Following the ratification of the Constitution,

as possible, to the diminution, and finally to the destruction, of that of the respective states"). Brutus did not deny the legitimacy of recourse to the spirit-he worried about abuses. See Brutus, Essay No. V, (N.Y. J., Dec. 13, 1787), reprinted in 2 ThE COMPLETE ANTI-FEDERALIST, supra note 88, at 389 ("It is a rule in construing a law to consider the objects the legislature had in view in passing it, and to give it such an explanation as to promote their intention. The same rule will apply in explaining a constitution."). Not all Anti-Federalists shared this precise concern-others worried that the spirit would be ignored. See Agrippa, Essay No. XVIII (MASs. GAZETTE, Feb. 5, 1788), reprinted in 2 The Debate ON THE CONSTITUTION 155, 156 (Bernard Bailyn ed., 1993) (fearing that "intention" of the Constitution would be disregarded).

266. The FEDERALIST No. 81, supra note 88, at 418 (Alexander Hamilton).

267. HAMBURGER, supra note 103, at 54; Natelson, supra note 155, at 1253-54.

268. THE Federalist No. 81, supra note 88, at 418 (Alexander Hamilton) (emphasis added).

269. See Commonwealth v. Caton, 8 Va. (4 Call) 5, 19 (1782).

270. The Federalist No. 81, supra note 88, at 418 (Alexander Hamilton).

271. Id.

272. The Federalist No. 32, supra note 88, at 156 (Alexander Hamilton).

273. Id. at 155-56; see also U.S. Const. art. I, § 10, cl. 2. Hamilton insisted that the Constitution granted federal and state governments "concurrent and co-equal authority" over general taxation. THE FEDERALIST No. 32, supra note 88, at 156 (Alexander Hamilton).

274. The Federalist No. 32, supra note 88, at 156 (Alexander Hamilton) (emphasis added). 
Hamilton would again have recourse to the spirit of the law in arguing that the Constitution authorized Congress to establish a national bank. ${ }^{275}$

There is no objection to recourse to the original spirit that cannot be made against textualist originalism more generally. Yes, identifying original functions may be hard. Yes, implementing original functions is an enterprise that is fraught with peril. But so is ascertaining the linguistic meaning of centuries-old text. We claim only that recourse to the original spirit is the best available means of implementing the original Constitution when the text runs out, even if it may well fall short of some unattainable ideal. ${ }^{276}$

\section{Conclusion: A Unified Theory of Originalism}

In this Article, we have presented a unified theory of originalist interpretation and construction. We maintain that originalism cannot do without the interpretation-construction distinction, nor can originalists deny the existence of the construction zone. But neither can originalism do without a methodology that equips judges to navigate the construction zone. We have advanced three propositions in this Article:

- First, judges are fiduciaries of the people to whom the Constitution entrusts a great deal of discretionary power, and that such wide discretion is the basis of corresponding fiduciary duties.

- Second, upon voluntarily taking their oath, judges become morally and legally bound to follow faithfully the instructions given them in the written Constitution.

- Third, to be faithful to "this constitution," judges should wield their discretionary power consistently with the "supreme law of the land" — both letter and spirit-resolving cases through the spirit where the letter fails.

If judges are to discharge what James Iredell described as "the duty of th[e] power" 277 delegated to them, they need a methodology to guide them in exercising their discretion: such discretion must be exercised in good faith rather than opportunistically. Good-faith construction recognizes that, even when the letter of the law gives out, the law does not-and neither does judicial duty to follow and enforce the Constitution's requirements.

275. Hamilton denied that recourse to the personal intentions of the Framers was appropriate- the legally binding intention was to be sought "in the instrument itself." Alexander Hamilton, Opinion on the Constitutionality of a National Bank (Feb. 23, 1791), in AleXANDER HAMILTON: Writings 613, 625 (Joanne B. Freeman ed., 2001). But in making his case for the constitutionality of the bank, he appealed to the "objects of [the government's] specified powers." Id. at 621.

276. Put another way, we urge textualist originalists to resist the "nirvana fallacy." See Harold Demsetz, Information and Efficiency: Another Viewpoint, 12 J.L. \& ECON. 1, 1 (1969) (criticizing policy analysis grounded in comparisons between imperfect existing institutions and unattainable alternatives).

277. James Iredell, Address to the Public (Aug. 17, 1786), in 2 LiFE AND CORRESPONDENCE OF JAMES IREDELL 144, 148 (Griffith J. McRee ed., N.Y., D. Appleton \& Co. 1857). 
It has been a mere thirty-eight years since Paul Brest introduced the term "originalism" into constitutional discourse, and even fewer since self-identified "originalists" first began developing its theory while researching the original meaning of the Constitution, clause-by-clause. Originalist interpretation is still in an early stage of development; good-faith construction has only just begun. It is, however, essential to completing the originalist project. 